\title{
Apostasy and Debauchery (1601-1660): Behaviour, Passive Evangelism and the East India and Levant Company Chaplains
}

Before the acquisition of territory became an objective, the mission of England's overseas companies was twofold: first, to ensure commercial success; and second, to govern their English personnel according to the laws, religion and government of England. Unlike the emphasis on communal enforcement in the theocratic governance of the MBC, the authority of the pastoral governance in the EIC and LC was imposed by individuals. For both companies, the figure of the chaplain and his role in policing the EIC's and LC's spiritual and secular authority became instrumental in ensuring the companies' religious governance. In an era when the EIC had no jurisdictive obligations, the primary concern for the chaplains in both companies was the spiritual well-being of the English personnel in the East. By policing the religious life of their personnel, the leaders of the LC and EIC sought to ensure the commercial success of the companies. Through the imposition of pastoral governance, the LC and EIC endeavoured to control the daily lives and exchanges of their corporate flock so that their spiritual well-being was not endangered in the religiously cosmopolitan environments in which the companies operated.

Foreign interaction in the early modern era was synonymous with spiritual risks and sinful temptations. It was the chaplains' role as a corporate police force abroad to enforce the companies' pastoral governance and try to prevent these risks from becoming realities. This involved the policing of behaviour and the punishment of it, when need be, whilst also guarding 
against apostasy. ${ }^{1}$ Through the position of the chaplain, both companies sought to protect their personnel against the religious 'other', securing not only their employees' spiritual and national well-being, but also their commercial mission. Treated in isolation, as agents of specific oceans and geographies, chaplains, and the companies that employed them, have rarely faced the scrutiny of comparison. Although on rare occasions there have been in-depth, biographical accounts of chaplains, these have tended to either focus on companies or individuals. ${ }^{2}$ In doing so, the company chaplains and their role have been simplified by neatly defining their differing roles in separate maritime geographies. Through a comparative assessment of the roles of the chaplains in policing communal interactions and knowledge exchange in England's seventeenth-century companies, we can better illustrate how English companies linked oceans.

The seventeenth-century company not only furnished the structure that allowed companies to trade, negotiate and govern overseas, but also provided individuals and organisations with frameworks to engage with new religious environments. From an early stage, chaplains or ministers were at the heart of the organisation of the company, not only as spiritual shepherds to the corporate flock but also as advisers, scholars and enforcers of the company's legal and moral code. Despite the scarcity of records, from very early on in the EIC's existence, chaplains were considered important for both the spiritual and temporal needs of the company. The first minister to be employed by the EIC and to be sent out on a ship was Thomas Pulleyn, who was considered so important he was paid more than the surgeon. ${ }^{3}$ By 1613, the EIC Court made formal attempts

${ }^{1}$ Emily Kugler, Sway of the Ottoman Empire on English Identity in the Long Eighteenth Century (Leiden: Brill, 2012), pp. 17-35; Haig Smith, 'God Shall Enlarge Japheth, and He Shall Dwell in the Tdents of Shem': The Changing Face of Religious Governance and Religious Sufferance in the East India Company, 1610-1670', in Pettigrew and Mahesh Gopalan, The East India Company, 1600-1857: Essays on Anglo-Indian Connection (New Delhi: Routledge, 2016), pp. 100-103.

2 Pearson, A Biographical Sketch; Conner, Chaplains; Glaisyer, Culture of Commerce, pp. 69-99; for individual chaplains, see Edward D. Neill, Memoir of Rev. Patrick Copland, Rector Elect of the First Projected College in the United States (New York, NY: Scribner \& Co, 1871); Leonard Twells, The Lives of Dr. Edward Pocock, 2 vols. (London: Rivington, 1816); Gerald M. Maclean, The Rise of Oriental Travel: English Visitors to the Ottoman Empire, 1580-1720 (Basingstoke, Hampshire: Palgrave, 2004), pp. 49-114; for a global comparison on English chaplains abroad in the early modern period, see Games, Web of Empire, pp. 219-254; Smith, 'Risky Business', pp. 226-247.

3 McNally, Chaplains, p. 69. 
to ensure that a chaplain was always present, suggesting that, just as they had employed a surgeon for 'the bodies of men, so they would be as prudent for supplying them with comfortable persons for the relief of their souls'. ${ }^{4}$ Beyond relieving the souls of the individuals under their clerical care, chaplains took part in various formal and informal negotiations. In 1613, Patrick Copland along with 'divers of our merchants' was sent ashore to 'dispatch business' regarding a local decree or 'firma [firman]'. ${ }^{5}$ Likewise, Robert Frampton's biographer recalls the preachers' important role following his arrival in Aleppo negotiating between the company, the Greek Orthodox community, and the local Ottoman leader. ${ }^{6}$ Representing godly virtue and scholarly learning, the chaplain was instantly recognisable to company personnel as representing a familiar symbol of authority, at sea or in far-off lands. To ensure that the standards of spiritual, moral and legal leadership delegated to the chaplain were high, company leadership at home and abroad took a keen interest in recruiting and managing the men they selected for the job. This chapter traces the evolution of pastoral governance in Asia and the Middle East prior to the EIC's and LC's territorial acquisitions. It focuses on the role of the chaplains, who were important figures in securing the companies' essential aims and establishing control over company personnel who went East.

Unlike the previous chapter, which emphasised the role of the religious community in the establishment of theocratic governance in the $\mathrm{MBC}$, this and the next chapter analyse the role of individuals in the developing pastoral governance in the EIC and LC. By investigating the chaplains' experiences of governing over a denominationally diverse English communities, interacting with foreign peoples of various faiths and cultures and being part of developing networks of information exchange, this chapter traces how individuals influenced religious governance in the East.

${ }^{4}$ BL IOR B/5 December 13, 1613.

5 Foster, ed., The Voyage Of Thomas Best To The East Indies 1612-1614 (London: Hakluyt Society, 1934), p. 142.

${ }^{6}$ LRF, pp. 34-35. 


\section{Protestant Pluralism and the Foundations of Pastoral Governance}

Both the LC and EIC embodied the plurality of the Protestant faith in England, attracting a broad spectrum of the Protestant population, which was reflected in their chaplaincy. In total, approximately 99 ministers were appointed over the century to go out to India or remain with the fleet. ${ }^{7}$ From those that can be traced, though, a broad array of Protestants seem to have been present in the company, such as conformist chaplains such as Henry Lord and Sir Thomas Roe's chaplain Edward Terry, the onetime Episcopalian and eventual Congregationalist Patrick Copland, and a few Presbyterians, Anabaptists and Baptists, as well as a Unitarian. ${ }^{8}$ This line-up of ministers with varying theological and liturgical backgrounds caused several problems that occasionally affected the social cohesion on ships and in factories. However, despite moments of internal division, the companies' Protestant communities abroad remained united.

Denominational variation was similarly illustrated in the leadership of the companies, which was frequently composed of members in both the EIC and LC as well as other overseas companies, including the VC and MBC. ${ }^{9}$ The first governor of the EIC, Sir Thomas Smythe, a moderate Puritan and ally of the Earl of Warwick, was deeply involved in English corporate expansion in the seventeenth century, being actively engaged in at least ten overseas companies. ${ }^{10}$ His involvement in the EIC would last for 25 years, eight as governor and seven at the King's request. Meanwhile, from 1600 to 1605 he was also governor of the Levant Company,

${ }^{7}$ McNally, Chaplains.

${ }^{8}$ Stern, Company-State, pp. 106-111.

${ }^{9}$ Rupali Mishra, A Business of State: Commerce, Politics and the Birth of the East India Company (Cambridge, MA: Harvard University Press, 2018) for the VC see p. 98: for the LC see pp. 225, 268.

${ }^{10}$ Smyth, a member of the East India, Levant, Muscovy and Virginia companies, and involved in the French, Spanish, Somer Isles and Northwest Passage companies, as well as the Merchant Adventurers. Edmond Smith, 'The Global Interests of London's Commercial Community, 1599-1625: Investment in the East India Company', The Economic History Review, Vol. 71, No. 4 (2018), pp. 1134-1135; For a broader discussion of the global interest of England's merchant community, see Smith 'Networks of the English East India Company, c. 1600-1625' (unpublished PhD diss., Cambridge University, 2015). 
a role he relinquished when appointed ambassador to Muscovy and treasurer of the VC. ${ }^{11}$ Over the same period, Smythe's political rival Sir Edwin Sandys (who was also treasurer of the VC) took up an active and often influential role in the company. A high Anglican, son of the Bishop of Worcester and accused Catholic convert, Sandys had long been a religiously controversial figure. ${ }^{12}$ Following the publication of Europa Speculum, Or A View or Survey of the State of Religion in 1605 (it went through three editions in that year), the long-standing rumours of his sympathetic leanings towards the Catholic Church seemed to have some truth in them. Wrapped in the rhetoric of Christian unity, Sandys called for toleration of Catholicism, to not only unite European Christendom but also secure it against the growth of Islam, the faith of both the Mughal and Ottoman Empires. ${ }^{13}$

The companies also attracted the attention of the influential ecclesiastical Abbot family. Maurice, the youngest of five brothers, was involved in the Levant Company, travelling to Aleppo in 1582 . He was also involved in the running of the EIC for 40 years, and was at varying points a merchant, director, deputy governor and finally governor from 1623 to 1636. ${ }^{14}$ It was through Maurice that his eldest brother George, the Archbishop of Canterbury (another elder brother Robert was also the Bishop of Salisbury), became involved in the company. ${ }^{15}$ The Calvinist-leaning archbishop had financial interests in the EIC, and was deeply involved in individual and group commerce, as it not only provided the opportunity to make money but also gain information on interactions between nonEuropeans and Europeans in Asia. ${ }^{16}$ Above all else, the archbishop and

${ }^{11}$ Mishra, Business of State, pp. 40, 80.

12 ibid, p. 69.

13 Sir Edwin Sandys, Europae Speculum. Or, A View or Survey of the State of Religion in the Westerne parts of the World (London: 1629), pp. 194-222; Theodore K. Rabb, 'The Editions of Sir Edwin Sandys's Relation of the State of Religion',Huntington Library Quarterly, Vol. 26, No. 4 (1963), pp. 323-336.

14 Mishra, A Business of State, pp. 102-107; Smith, 'Global interests', p. 1125.

15 Mishra, A Business of State, pp. 122, 184.

16 For George Abbot's stock in the EIC, see Cal. SP, 1513-1616, 616, 786; for more information on Abbot, see Fincham, 'Prelacy and Politics: Archbishop Abbot's Defence of Protestant Orthodoxy', Historical Research, Vol. 61 (1988), pp. 36-64; S. Holland, 'Archbishop Abbot and the Problem of Puritanism', Historical Journal, Vol. 37 (1994), pp. $23-43$. 
his successor Laud both valued their correspondence with chaplains. ${ }^{17}$ For both Abbot and Laud, the chaplains of the Levant Company offered a bridge to open relations between the Church of England and the Greek Orthodox Church. For Laud, the chaplaincy of the Levant Company also provided him with a network of individuals through whom he could obtain Middle Eastern manuscripts and establish a library at Oxford. Likewise, correspondence with the Roe embassy provided Abbot with information and observations on the religions of the Indian court. ${ }^{18}$ The varied Protestantism that characterised the company government, leaders and supporters in England was similarly representative of those agents, factors and chaplains who went abroad and established company governance in India and the Ottoman Empire, in this period. The internal religious disjointedness required the companies in this early period to ensure that they established their own form of stable pastoral governance over their English communities abroad. Essential to the formation of the pastoral governance of the LC and EIC in this early period was the chaplain, who ensured that it was policed and maintained.

\section{Pastoral Governance and Preventing Apostasy}

An important role of the company chaplain and pastoral governance was preventing apostasy or 'turning Turk.' For the EIC and LC, the chaplains were the first line of defence against apostasy and the threat posed was to the spiritual and national identity of their personnel. The companies believed that the chaplains' 'clerical approval could mitigate' the 'collective peril' of any religiously diverse society the English found themselves in. ${ }^{19}$ Despite this, tales of conversion and apostasy were not uncommon and whether or not it was an actual threat, the company perceived it to be so. ${ }^{20}$ The links between religious faith and national identity meant that conversion posed a serious threat to the leadership of the EIC and LC, as they perceived themselves to be the governing body that represented the English national identity abroad. Conversion

17 Mishra, Business of State, p. 286.

18 O'Connor, Chaplains, pp. 4-6.

19 Games, Web of Empire, p. 223.

${ }^{20}$ For more information on conversion threats, see Stern, Company-State, p. 105; G V. Scammell, 'European Exiles, Renegades and Outlaws and the Maritime Economy of Asia c. 1500-1750', in Modern Asian Studies, Vol. 26 (1992), pp. 658-659. 
then was not only a disgrace to one's country and faith, but also a threat to the company's authority. Conversion removed Englishmen from the company's sovereignty, weakening their authority and position, as well as endangering their commercial aims. Due to this threat, it was not only the chaplains' godly duty, but also their corporate mission, to prevent apostasy through the companies' pastoral governance, thereby securing the companies' commercial objectives.

Unlike the VC and the later EIC, neither company (apart from the Fort St. George) held jurisdictive control of land outside their factories in this period, and so their pastoral governance evolved to meet the demands of these religiously cosmopolitan environments. These pressures included the behavioural issues of English personnel abroad, apostasy, diplomacy and knowledge exchange, all of which the company chaplains were heavily involved in policing. The chaplaincy became a corporate police force that not only governed over the behaviour of the company's personnel, but also oversaw several of the companies' external interactions with local peoples of varying faiths. These interactions marked the limit of the companies' control over indigenous peoples and so restrained its evangelical aims. Unwilling to jeopardise the companies' commercial and diplomatic missions, the chaplains of the EIC and LC rarely sought to actively evangelise. Differing from their counterparts in the $\mathrm{VC}$ and the Iberian companies, English chaplains adopted a form of passive evangelism that would epitomise English religious governance in the East during the seventeenth century. As influential figures, chaplains in the EIC and LC would not only effect the evolution of religious governance abroad in this period. They became senior figures in every aspect of company life, acting as confidant and advisers to officials, and at times engaging in diplomatic and commercial missions themselves. Furthermore, chaplains also had their own motives, entering company life to travel abroad and engage in trade, evangelism and education with the hope of furthering their own careers and prospects on their return home.

Despite some years of religious acclimatisation, both the EIC and LC would continue to be worried about the threat of English personnel converting. By employing an able minister, company officials hoped to avoid any scandal that would weaken their religious governance and authority, and as such the Almighty would 'prosper us, in all such 
designs, \& endeavours we undertake'. ${ }^{21}$ Although it is difficult to quantify how many of the English peoples converted over this period, it can be presumed that the number was small, since relatively few occurrences are recorded. For those who were captured by Barbary pirates and forced into servitude as galley slaves in the Mediterranean, it has been suggested around four per cent converted. ${ }^{22}$ However, avenues for apostasy such as marriage, or even unprovoked conversion, are much harder to quantify. Not only were EIC and LC officials worried about the spiritual ramifications of conversion, but also the implications of an individual's conversion on foreign opinions of the nation. To ensure commercial security and the nation's good name, LC and EIC officials were vigilant that company employees remained in the fold of the Anglican faith. In 1640, the LC chaplain Bartholomew Chappell was ordered in Aleppo to not only preach the word of God, but to 'administer the Sacraments, according to the Canons and Constitution of the Church of England'. ${ }^{23}$ Such a move suggested a denominational allegiance that had not always been shared amongst members of the company abroad. This may have had to do with the religious divisions in England at the time, but was most probably an inadequate gesture by company officials to make it appear as though they were enforcing the Church of England's presence amongst their English communities abroad. ${ }^{24}$

Despite attempts to allay conversion, both companies continued to receive reports of apostasy in this period. In 1599, Thomas Dallam wrote of a 'Turke, but a Cornishe man borne' whilst John Rawlins wrote back about a man called 'Ramtham Rise' formerly 'Henry Chamdler... a chandler's son in Southwark' ${ }^{25}$ Apostasy presented such a worry that apostates from other European countries were often noted and discussed

21 TNA SP. $105 / 109$ f.191.

22 Games, Web of Empire, p. 73.

23 Quoted in Pearson, Biographical Sketch, p. 61.

24 Christine Laidlaw suggests that in the choice of ministers, as well as the LC's own denominational allegiance there was none, and that it would be difficult to prove otherwise: Laidlaw, The British in the Levant: Trade and Perceptions of the Ottoman Empire in the Eighteenth Century (New York, NY: Taurus, 2010), pp. 78-79.

25 'The Diary of Master Thomas Dallam, 1599-1600', in J. Theodore Bent, ed., Early Voyages and Travels in the Levant (London: Hakluyt Society, 1893), p. 79; John Rawlins, The Famous and Wonderful Recovery of a Ship of Bristol called the Exchange, from the Turkish Pirates of Argier (London, 1622), p. 270. 
offering illustrations of the threat of conversion, but also as examples of European or Catholic weakness. Furthermore, they represented the successes of English Protestants in bringing apostates back to the Christian faith. Frampton recalled meeting two individuals whilst in Aleppo who had converted to Islam, the first a Frenchman who had served with the Venetian army and had been taken captive and been freed when he converted to Islam. ${ }^{26}$ Frampton's biographer then provides a detailed account of the discussion between the preacher and the apostate, which ends with the latter repenting and Frampton ordering him to 'leave then the tents of these wicked men and repair to Christendom'. ${ }^{27}$ The second individual was a Portuguese friar who, unlike the former 'which necessity put upon desperate course', chose to willingly or actively convert, or as Frampton's biographer describes, 'ran headlong into the ways of errour to gratify a more licentious appetite to scandal and grief of Christians'. ${ }^{28}$ Again following a similar format, in which the nature of the individual's conversion, his background and the nature of the Christian covenant was discussed, Frampton was able to 'bring him out' of his state of apostasy and back into 'his Saviour's fold'. ${ }^{29}$ The extra degree of separation allowed for company agents and chaplains to interact with these converts differently, often employing them as middlemen, whilst remaining vigilant of their loyalties. ${ }^{30}$ These men are examples of a group of individuals who, despite being in the minority of those who travelled east, were the focus of much concern from English officials both at home and abroad forcing companies to adapt their religious governance to deal with the threat.

Regardless of attempts to prevent the conversion of their personnel to Islam or Catholicism, it was often the case that the companies did not have the power to prevent apostasy but could only rectify it. One such case took place in the spring of 1649, when President Thomas Breton wrote of his grief to 'impart unto you a sad story' of the 'damned apostasy' of a factor at Agra, who had brought both 'dishonour to our nation,

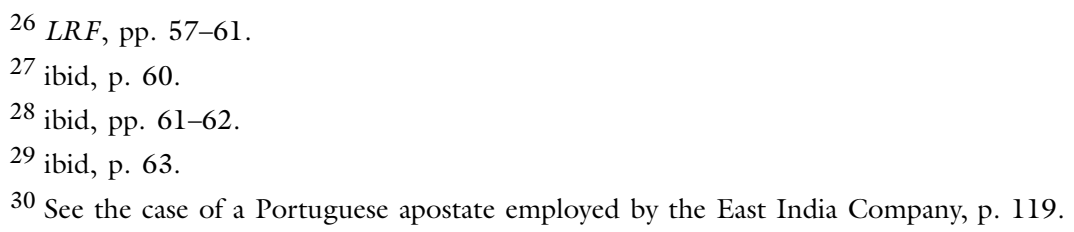


and (which is incomparably worse), of our Christian profession'. ${ }^{31}$ Breton explains that following Sunday prayers, Joshua Blackwell went to the governor of the city and had an audience with local religious leaders, following which he 'wickedly and desperately renounced his Christian faith' converting to Islam, upon which he was 'immediately circumcised' and 'irrecoverably lost'. ${ }^{32}$ Breton's assertation that Blackwell was lost forever lay in his knowledge of Mughal law, which prevented any interaction that would lead to the reconversion of Englishmen who had become Muslim. Over the next year, Blackwell was frequently mentioned in letters between company officials in India. Factors were informed of his 'poor and wretched temporal condition' as well as his theft of a company horse. ${ }^{33}$ Yet, despite Breton's belief that Blackwell was beyond 'redemption', in the months that followed, Blackwell initiated a series of correspondences starting in February 1650, when he was reported to have 'repented his apostasy and returned to the true faith'. ${ }^{34}$ Travelling first to Lahore, and eventually arriving in Surat, Blackwell was eventually readmitted into the company and the Protestant community it represented. ${ }^{35}$ Even 'upon the acknowledgment of his sin and promise of perseverance in his Christian profession', Blackwell was still unable to remain in India and would instead be sent to the Middle East to be a factor at Basra or Mocha. ${ }^{36}$ The EIC's chaplain in Surat, William Isaacson, who had been placed in charge of Blackwell's re-admittance into their society, wrote of the difficulty he would face if he continued to be employed by the EIC in Surat, explaining that he would be 'subject to the abuse of every

${ }^{31}$ BL IOR E/3/21 President Breton and Messrs. Merry, Pearce and Oxenden at Swally Marine to the Company, April 5, 1649.

32 Ibid.

33 BL IOR E/3/21 President Merry and Messrs. Tash, Pearce and Oxenden at Swally to the Company, January 25, 1650; Instructions from the President and Council at Surat to Richard Davidge, Proceeding to Court, March 7, 1650.

34 BL IOR E/3/21 Joshua Blackwell at Agra to the President and Council at Surat, February 14, 1650.

35 BL IOR E/3/21 Letter from the President and Council at Surat to the Factors at Agra, March 7, 1650.

36 BL IOR E/3/21 The Rev. William Isaacson at Surat to Joshua Blackwell [at Agra], March 7, 1650. 
Mahometan that knows your condition'.37 Although Blackwell would have made a sorry example, there were times when English converts did cause the EIC and LC problems. One such instance occurred in Istanbul, where the LC reported that a William Trednock, who refused to join Islam whilst in captivity, did so upon his release at the persuasion of yet another unnamed English apostate, disappearing from the English records altogether. ${ }^{38}$ When it came to apostasy, the chaplain and the companies' pastoral governance provided two services: firstly, to prevent apostasy and secondly, to manage its damage.

It was not just conversion to Islam that the EIC and the LC were guarding against; they were also ever conscious of the presence of Catholicism. In 1648, Thomas Ivy, a factor at Fort St. George, reported with great urgency to the EIC that the grandson of the founder of the fort had 'turned Papist rouge' and fled to the informal Portuguese settlement at Sāo Tomé de Meliapor (Mylapore). ${ }^{39}$ The company replied by sending letters to Filipe de Mascarenhas, the Viceroy of Goa, to return him to India. In the event of failure, Breton would be sent to 'require him'. ${ }^{40}$ In the LC, Benjamin Lannoy, Consul in Aleppo, was ordered by the company to 'administer the Oath of Allegiance' to all members of the factory, partly to help judge whether they were 'disaffected to his Majesties Church of England'. ${ }^{4}$ The order informed Lannoy that those whom he believed to be 'disaffected' were to be refused protection and any who refused to take the oath were to be sent 'by first opportune conveyance for England' to be punished. ${ }^{42}$ By ensuring the presence of some form of Protestant Church of England, the EIC and LC sought first to prevent their English personnel from being drawn to the Catholic Church and second to damage the influence of Catholic nations at the Mughal and Ottoman courts.

37 BL IOR E/3/21 Instruction for President and Council at Surat to Richard Davidge, Proceeding to Court, March 7, 1650; Isaacson to Blackwell, March 7, 1650.

38 TNA SP $105 / 74$, f.281.

39 Thomas Ivy at Fort St. George to the President and Council at Surat, January 17, 1648, in Foster, English Factories, VIII: p. 298.

40 Ibid.

41 TNA SP. $110 / 56$, f. 213.

42 Ibid. 


\section{Pastoral Governance and Structuring Diplomatic Interaction AND Response to Iberian Presence}

Company chaplains in both the Levant and India had to deal with the presence of an organised Catholic mission, which not only compounded commercial and national rivalries, but also competition between the governance of Catholic and Protestant companies. In 1599, the Venetian bailo to Istanbul reported of the attempts of the LC and its ambassador, Henry Lello, to build an Anglican Church in the Ottoman Empire. Writing back to the doge and the senate, he declared that the Venetians and the French had enough influence to "thwart this excessive and arrogant pretension of the English, who would endeavour to sow even here the perversity and impiety of Calvin'. ${ }^{3}$ Since the Reformation, the Roman Catholic Church had taken a series of steps to try and ensure that the influence of Protestantism did not reach the Middle East. This movement culminated in 1622 when Pope Gregory XV established the Sacra Congregatio de Propaganda Fide that sought to actively regulate Christian ecclesiastical affairs in non-Christian countries. With the establishment of the Propaganda Fide, Capuchin, Carmelite and Jesuit missionaries planted themselves across the Middle East and Asia. ${ }^{44}$ The strong presence of Catholic religious apparatus in Asia and the Middle East not only heightened the commercial and religious paranoia of EIC and LC leaders, but also provoked a response in the religious governance of the companies. Pastoral governance in eastern companies, just as in the VC, adapted in response to the presence of Catholicism, establishing its own solutions for evangelism, inter-faith interaction and policing behaviour.

For the leadership of both companies, the chaplaincy was the first defence against the aspirations of the Roman Church and what they believed to be antagonistic commercial desires of the Catholic nations,

43 Girolamo Capello, Venetian Ambassador at Constantinople, to the Doge and Senate, October 2, 1599, Horatio F. Brown, ed., Calendar of State Papers, Venetian 1592-1603, vols. 38 (London: Public Records Office, 1897), IX, p. 817.

44 Felicita Tramontana, 'The Spread of Catholicism in Seventeenth-Century Palestinian Villages', in Giuseppe Marcocci, Aliocha Maldavsky, Wietse de Boer and Ilaria Pavan, eds., Space and Conversion in Global Perspective (Leiden: Brill, 2014), pp. 83-102; Charles A. Frazee, Catholics and Sultans: The Church in the Ottoman Empire, 14531923 (Cambridge: Cambridge University Press, 2006), pp. 67-102; Xavier and Županov, Catholic Orientalism, pp. 107, 291-300. 
a view that was mirrored by their Catholic counterparts. ${ }^{45}$ In March of 1600, Sir Thomas Smythe wrote to the minister at Aleppo, William Biddulph outlining his duties that you will continue and proceed in your charge... in the instruction of our people in knowledge of Religion'. ${ }^{46}$ The presence of the Portuguese in India concerned many in the EIC who believed they threatened their commercial and diplomatic mission. In 1613, Thomas Kerridge wrote to the council at Surat that a foreigner 'if not presented by the Jesuit, hath no grace at all'. ${ }^{47}$ The same year, William Biddulph, a company factor, wrote to the governor and East India Company that the Jesuits hindered the progress of the English in India. According to Biddulph, Kerridge had been sent to Agra, amongst other things, to 'resolve the King of all such matters these prating Jesuits put into his head', which he concluded had prevailed in 'telling him we are a base people and dwell in a little island'. ${ }^{48} \mathrm{By}$ December 1613, the presence of the Jesuits had become so problematic that the leadership of the EIC in England took formal steps to tackle Catholicism in India. The court ordered that the ministers be selected on their ability to spar with the growing Catholic presence in India, writing that each person should have the learning and knowledge to oppose the Jesuit'. ${ }^{49}$ In the Levant Company, preachers also had to deal with a strong Catholic presence, whilst in Aleppo, Robert Frampton 'had often occasion to show his learning in defence of the Church of England', especially after making the acquaintance of a Jesuit Georgio Rihelio, resident at the French consul's house. ${ }^{50}$ According to Frampton's biographer, the two

45 Xavier and Županov, Catholic Orientalism, p. 83.

46 Sir Thomas Smythe to William Biddulph, March 1600, quoted in Maclean, Oriental Travel, p. 54.

47 Thomas Kerridge at Agra to Thomas Aldworth and Counicl at Surat, September 7, 1613, in Frederick Danvers, ed., Letters Received by the East India Company from its Servants in the East, 6 vols. (London: S. Low \& Marston, 1896), I: pp. 282-283.

48 William Biddulph to the Right Worshipful Sir Thomas Smythe, Kinght, Governor, the Deputy and rest of the merchants trading to the East Indies, 28 October 1613, Danvers, Letters Received, I: p. 300. This is not the same William Biddulph that was employed by the LC.

49 BL IOR B/5 A Court of Committee, December 13, 1613.

50 LRF, p. 55. 
would often engage in religious discussion although after 'much argument' they 'mutually despair'd'. ${ }^{1}$ However, in order not to 'scandal [for] the poor Christians there' or cause confusion, both men agreed to outwardly observe 'strict friendship between themselves'. ${ }^{2}$ As Frampton's relationship with Rihelio shows, although religiously antagonistic it was not impossible for the members of the EIC and their Catholic counterparts to get on. Indeed, across the Middle East and Asia there were many moments of cooperation between the two communities. In 1631, Thomas Rastell, president of the factory at Surat, contacted Jesuits in Goa to initiate peace talks between the English and Portuguese. ${ }^{53}$ Although unsuccessful, this was the beginning of a series of exchanges between the English, Jesuits and Portuguese that was often based on trust and friendship between individuals. ${ }^{54}$ Again in 1633, President William Methwold contacted Farther Tavares and the Jesuits in Daman to initiate peace talks between the EIC and the Portuguese, who replied that they would do what they could to 'effect so laudable an object'. ${ }^{5}$ Methwold's relationship with Tavares continued for several years, the latter at one point arranging for the president to stay with the Jesuits in Goa, where he would later represent the English to the Viceroy in order to secure a peace accord between the two nations. ${ }^{56}$ Religion and its governance became a key element in the LC and EIC plans to assert themselves diplomatically and commercially abroad. Religious differences between the EIC and their Catholic counterparts in the Levant and India did not always result in antagonism; instead, beyond Europe their shared Christianity often resulted in friendship and diplomatic support.

The need for a strong chaplaincy and Protestant presence led the EIC and LC to develop pastoral governance, which would increasingly influence interactions with local leaders and officials in this period. Arriving in religiously cosmopolitan environments, chaplains and personnel often

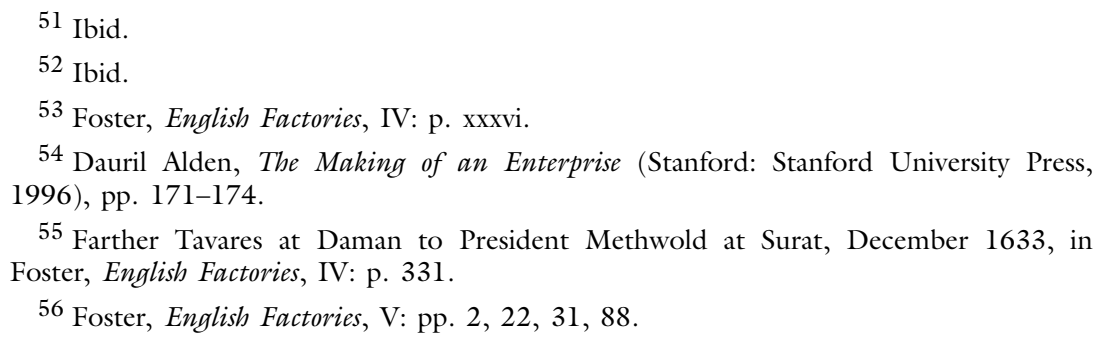

55 Farther Tavares at Daman to President Methwold at Surat, December 1633, in Foster, English Factories, IV: p. 331.

56 Foster, English Factories, V: pp. 2, 22, 31, 88. 
commented upon religion whilst abroad. Several of the EIC's chaplains and personnel were to write about the policy of religious toleration in the Mughal Empire. The ambassador to the Mughal Empire, Thomas Roe, later recalled a dinner party at the court where Jahangir, the Mughal emperor, drunkenly declared that 'he meddled not' with the faith of 'Christians, Moores, [and] Jewes', ${ }^{57}$ According to Jahangir, merchants, diplomats, pilgrims and artisans of all faiths came to India 'in love' and as such 'he would protect them from wrong. ${ }^{58}$ Although Roe's account of the drunken emperor is most likely apocryphal, it should not be dismissed. Jahangir's attitudes towards religion were complex and, like his father Akbar's religious policies, could be considered tolerant. ${ }^{59}$ Edward Terry, Roe's chaplain, suggested that the policy of religious toleration offered by the Mughal Emperors allowed for their 'tyrannical government there to be more easily endured'. ${ }^{60}$ Many of those who ventured to India in this early period wrote back perplexed by the exotic combination of religious toleration with Mughal despotism. ${ }^{61}$ Terry later recalled a story in which Thomas Coryate shouted from a building opposite a mosque in Surat at a 'Moolas' performing the call for prayer. In response to the muezzin's call to prayer, Coryate reportedly exclaimed back 'La alla illa alla, Hasaret Easa Ben-alia; that is, no God, but one God, and the Lord Christ, the Son of God'. ${ }^{62}$ To add insult to injury, Coryate then went on to undiplomatically declare that 'Mahomet was an imposter' ${ }^{63}$ The chaplain goes on to write that Coryate was lucky to be in India for 'every one there hath liberty to profess his own Religion freely and if he please may

57 Foster, ed., The Embassy of Sir Thomas Roe to the Court of the Great Mogul, 16151619, 2 vols. (London: Hakluyt Society, 1899), II: p. 382.

58 Ibid.

59 For an insight into Jahangir's own religious perspective and how this affected his religious policy, see Sajida S. Alvi, 'Religion and State during the Reign of Mughal Emperor Jahăngy̌r (1605-27): Nonjuristical Perspectives', Studia Islamica, No. 69 (1989), pp. 95119; Athar Ali, Mughal India: Studies in Polity, Ideas, Society and Culture (New Delhi: Oxford University Press, 2006), particularly chapter 16.

${ }^{60}$ Edward Terry, A Voyage to East-India (London: 1655), p. 418.

61 Joan-Pau Rubies, 'Oriental Despotism and European Orientalism: Botero to Montesquieu', Journal of Early Modern History, Vol. 9 (2005), pp. 146-148.

62 Terry, A Voyage, p. 271.

63 Ibid. 
argue against theirs, without fear of an inquisition'. ${ }^{64}$ Coryate himself would also go on to proclaim that the Mughal emperor 'speaketh very reverently of our Saviour' and that 'all Christians, especiallie us English, he useth so benevolently'. ${ }^{65}$ For much of this early period, misunderstanding and miscommunication not only defined the English response to local religious governance, but also how the company officials established and communicated their own pastoral governance and religious identity to local peoples and elites.

The companies' early interactions in these new geographies were often marked by the ability of its chaplains and personnel to successfully interact with several powerful local religious and cultural groups. Roe's accounts provide an insight into how Christians abroad presented their religion, or at least how they wanted others to believe their faith was being represented abroad. ${ }^{66}$ One example of this in Roe's recollections is a discussion with Jahangir on slavery, in which he declared triumphantly, and somewhat ironically, to the emperor 'that Christians keep no slaves' when the Mughal emperor offered to sell him two young boys. In what may be described as a brash diplomatic move, Roe goes on to describe how he very publicly bought the children to set them free to illustrate the mercy of Christian governance. ${ }^{67}$ Neither the smugness in Roe's account, nor the underlying friction surrounding religious governance and identity between company personnel and their hosts, are uncommon for this period. Furthermore, these incidents illustrated how company officials presented English authority and religious governance to foreign rulers, or their readers, as a constant that was untouched by foreign interactions. Roe could have easily accepted the slaves; however, to his readers he emphasised his actions as being in line with Christian practice. To his readers, this would have been a comforting reminder that good Christian

${ }^{64}$ Ibid.

65 Thomas Coryate, Thomas Coriate traveller for the English wits: Greeting From the Court of the Great Mogul, Resident at the towne of Asmere, in easterne India (London, 1616), pp. 23-24.

66 Rupali Mishra, 'Diplomacy at the Edge: Split Interests in the Roe Embassy to the Mughal Court', Journal of British Studies, Vol. 53, No. 5 (2014), pp. 5-28.

${ }^{67}$ Roe wrote that he was 'resolved to pay the money, but so as the King should not be ignorant I had more mercy then he, and that a Christian esteemed the life of a Moore above money'; quoted in Foster, Sir Thomas Roe, p. 305. 
behaviour was not corrupted abroad, and that it continued to be enforced and advertised by the English abroad.

In another account from Japan, the EIC agent there, Richard Cocks, wrote back describing the difficulties that Christians faced in the country. In 1613, in a letter to Richard Wickham, a merchant at Hirado, Cocks discussed the difficulty of translating both national and religious imagery across cultures, describing how he was 'full sore against [his] will' forced to take down the English flag. ${ }^{68}$ Cocks goes on to recall an argument between him and a local Japanese official who believed that the St. George cross was a crucifix. Cocks, at the insistence of the Japanese authorities, took down the flag, following his inability to suitably explain the religious and national symbolism it represented. This incident illustrates two issues: firstly, the difficulties English officials faced in explaining their religious identity across cultures during this period, and secondly, how company officials were powerless to resist the local authorities, whether religious or secular. Much like Roe in his discussion with Jahangir over slavery, Cocks some years later sought to define his Protestant faith in contrast to Catholicism. He explained to the Japanese emperor that, unlike the Portuguese, whose religion was governed by an outsider, the Pope, in England the King was head of the Church. ${ }^{69}$ Consequently, the English Protestants were not as weak as their Catholic counterparts, as no outsider interfered in the governing of their faith. ${ }^{70}$ Attempts by company officials to explain the distinctions between the forms of religious governance and denominational identities of European nations were often further complicated by the reaction of local rulers to aspects of Christian religious governance, in particular evangelism. To secure both their religious and commercial missions, company leaders would have to ensure that chaplains rigidly enforced their pastoral governance. In doing so, the behaviour of the companies' personnel would be secured, ensuring good commercial relations. At the same time, the leaders of the EIC and LC hoped that they would succeed in passive evangelism through securing their English people's daily, supervised interactions.

68 BL IOR E/3/1 Richard Cocks at Shrongo to Richard Wickham, March 1614.

69 BL IOR G/12/15 Richard Cocks at Firando to EIC January 1 \& 14, 1617.

70 Ibid. 
A crucial element, and shared aspect, of pastoral governance in this period was the call to evangelise. In doing so, both Catholic and Protestant national companies competed to expand and secure not only the souls of, but also their nation's jurisdictive rights over, peoples traditionally considered beyond their realm. National rivalry alongside the well-documented presence of the Iberian nations in the Mediterranean, Indian Ocean and Pacific Ocean helped the EIC and LC to tailor a form of religious governance and evangelism that could be seen as opposing the Catholic companies' predilections. Upon arriving in Japan, EIC officials often wrote back lamenting the presence of Catholics, proclaiming, 'there be many Christians by reason of the Jesuits' and that 'in this land there are many Christians according to the Romish order'. ${ }^{71}$ However, from the outset, EIC personnel who ventured to Japan seemed to be both surprised by but also wary of the uneasiness of the local leadership about the strong Catholic presence in the nation. Writing back in 1611, William Adams made it a point to not only describe how the people of Japan, through the imposition of 'law without partiality', were 'governed in great civility', but also that, despite the seemingly strong Catholic presence, were still 'very superstitious in the religion'. ${ }^{72}$

The presence of a strong and successful Jesuit mission in Japan further complicated issues, as Japanese leadership grew increasingly hostile towards Christianity. ${ }^{73}$ Under the political leadership of Toyotomi Hideyoshi and Tokugawa Ieyasu, Japanese religious relations with European powers had become increasingly tenuous and by 1614 the Jesuits, along with other Catholic orders including the Franciscans, had been exiled. ${ }^{74}$ Although on occasion Catholic authorities complained of other European agents such as the English sailor William Adams being an obstacle to improving relations, the gradual deterioration in relations was compounded by a number of issues aside from commercial and spiritual rivalry. Apart from evangelism and European antagonism, Japanese

${ }^{71}$ BL IOR E/3/1, William Adams at Hirado to Bantam, October 23, 1611; William Adams at Hirado to Augustine Spalding at Bantam, January 12, 1613.

72 BL IOR E/3/1, October 23, 1611.

73 Charles R. Boxer, The Christian Century in Japan 1549-1650 (Berkley, CA: University of California Press, 1967); J. F. Moran, The Japanese and the Jesuits: Alessandro Valignano in sixteenth century Japan (London: Routledge, 1993).

74 Boxer, The Christian Century, pp. 137-184, 315-316. 
leaders such as Hideyoshi and Ieyasu feared that Catholicism was a potentially disruptive and dangerous element in the new unified Japanese sociopolitical order. ${ }^{75}$ As one Jesuit proclaimed, they were exiled 'because the law we preach is contrary to the kami (ancient ancestors) of Japan' and that it was 'directly destructive of the honour and reputation of the lords of Japan, for the kami are simply the lords of Japan themselves'. ${ }^{76}$ Furthermore, there was a growing perception amongst Japanese leaders that Catholic converts were a fifth column in the service of Portugal and Spain, undermining Japanese society in preparation for an invasion. Initial reports from EIC personnel of the Jesuits' banishment were met with surprise, with one agent writing he 'doubt[ed] the news is too good to be true' that 'all the papist Jesuits, Friars and Priests shall be banished out of Japan'. ${ }^{77}$ Over the next few years, factors repeatedly informed the company of the banishment of the Catholics from Japan and expressed concern for the reputation of their faith, as 'the name of Christian is odious to them' ${ }^{78}$ On top of this, company personnel complained that the Jesuits were blaming the English for their apparent misfortune. Cocks, on several occasions, wrote that the Catholics 'laid the fault of this alteration on the arrival of our nation in these parts'. ${ }^{79}$ However, he also

75 Adriana Boscaro, 'Toyotomi Hideyoshi and the 1587 Edicts Against Christianity', Oriens Extremus, Vol. 20, No. 2 (1973), pp. 219-241; Timon Screech, 'The English and the Control of Christianity in the Early Edo Period', Japan Review, Vol. 24 (2012), pp. 4-8; Carla Montane, Sacred Space and Ritual in Early Modern Japan: The Christian Community of Nagasaki (1569-1643) (unpublished PhD diss., SOAS, London: 2012), pp. 114-134, 218-249; Nam-in Hur, Death and Social Order in Tokugawa Japan: Buddhism, Anti-Christianity, and the Danka System (Cambridge, MA: Harvard University Asia Centre, 2007), pp. 37-58.

76 Cartas que los Padres y Hermanos de la Compañia de Jesús, que andan en los Reynos de Iapon, escrivieron a los de la misma Compañia, desde el año de 1549 hasta el de 1574 (Alcalá, 1575), Vol. 2, 258b, quoted in Moran, the Japanese and the Jesuits, p. 77.

77 BL IOR E/3/1 Richard Cocks at Hirado to Richard Wickham at Edo or Shizouka, February 17, 1614; BL IOR G/40/25 Richard Cocks at Hirado to John Jourdain at Bantam, December 10, 1614.

78 BL IOR E/3/1 Richard Cocks at Hirado to Richard Wickham at Edo, Shizuoka or Elsewhere, March 7, 1614; BL IOR E/3/2 Richard Cocks at Hirdao to the EIC in London, November 17, 1614; Richard Cocks at Hirado to Adam Denton at Pattani, November 25, 1614; BL IOR G/12/15 Richard Wickham at Hirado to EIC in London January $15,1617$.

79 BL IOR G/40/25 December 10, 1614; BL IOR E/3/3 Richard Cocks at Hirado to Richard Westby at Bantam, February 25, 1616. 
concludes that it was 'notorious to all men that their own covetousness and ill behaviours' had led to their banishment. ${ }^{80}$ Similarly, Wickham asserted that the accusations levelled by the Jesuits and other Catholics at the English were ill-founded and that it was 'the subtle practices \& covetous dealing[s]' of the Jesuits' practices that had 'scandaled' the Emperor and caused him to act against them. ${ }^{81}$

Wickham's letter embodies the religious animosity between the Protestant English companies and their European Catholic counterparts, placing evangelism at the centre of the growing competition to increase commercial and national reputations. According to one EIC agent, although the English were not the main factor for the banishment of the Jesuits, they had 'upon demand, as occasions offered... done the Jesuits little credit'. ${ }^{82}$ Critical of the Jesuits' aggressive evangelism, perceiving it to have been the cause of their banishment, EIC agents also lamented how it had also led to the religious persecution of 'Japon Christians'. ${ }^{83}$ By 1620, multiple accounts of persecution had been sent back to England, including reports of churches being burnt down, people being forced to recant and several massacres across the country. ${ }^{84}$ The experiences and insights of the EIC in Japan, involving Catholic evangelism and Christian persecution abroad, draws attention to the motivations for the evolution of pastoral governance and passive evangelism in the company. Pastoral governance, unlike the reported aggressive religious policies of the Portuguese, provided the structural framework to secure the English commercial dominance as well as impose the authority of the company on its own personnel. In doing so, it allowed the English companies to proselytise through the policing of their personnel's behaviour.

80 Ibid.

${ }^{81}$ BL IOR G/12/15 Richard Wickham at Edo to Sir Thomas Smyth in London, October 23, 1615 .

82 Ibid.

83 Ibid.

${ }^{84}$ BL IOR E/3/1 William Eaton at Osaka to Richard Wickham at Edo, March 1, 1614; BL IOR G/40/25 December 10, 1614; BL IOR E/3/7 Richard Cocks at Nagasaki to Sir Thomas Wilson in London, March 10, 1620. 


\section{Chaplains as Enforcers of Pastoral Governance AND Corporate Evangelism}

To ensure the good behaviour of company personnel abroad, chaplains were vital enforcers of the companies' pastoral governance. Their presence was considered key to the success of the commercial missions of the EIC and LC, which in both cases was prioritised over evangelism, as for this early period, although a concern, it was not a pressing issue. ${ }^{85}$ As early as 1610, an EIC official told a chaplain that 'civil behaviour is very requisite for begetting love and estimation amongst those heathenish people'. ${ }^{86}$ In order to do this, his primary aim was to 'settle such modest and sober government' that would ensure good behaviour of the company's English personnel. ${ }^{87}$ For the EIC, obtaining the 'love and estimation' of the Indian people through good behaviour had two connected and independent meanings. The first was the financial and commercial support of local merchants, helping the company to establish and maintain its business, whilst the second was related to eventual conversion of local people to Christianity. The behaviour of personnel abroad had long been a worry for the leaderships of both companies. The Levant Company factor, John Sanderson, wrote back to London that whilst in Istanbul 'a jolly set of divers devils, fools, madmen, antiques, monsters, beasts, [and] whoremongers' had surrounded him. ${ }^{88}$ Many in both the LC and EIC believed that, to ensure the success of the trading mission of the company, they needed to ensure the good behaviour of its personnel, and so this fell to the authority of the company chaplains.

Punishments were enforced for several different infractions, including drunkenness, swearing, absence from services, or prayer and blasphemy, and almost all of them involved a fine, as this was considered the most effective way of ensuring that men could not get hold of drink. ${ }^{89}$ The EIC were quick to realise this required a lot more policing than was

85 Mills, Commerce of Knowledge, p. 213.

86 Quoted in O'Connor, Chaplains, p. 48.

87 Ibid.

88 Sanderson at Pera to Nicolas Leate in London, March 1600, Foster, ed., The Travels of John Sanderson in the Levant, -1602 (London: Hakluyt Society, 1930), p. 197; Wood, History of the Levant, p. 224.

${ }^{89}$ Foster, Thomas Best, p. 95. 
first expected, leading factors to plead with the company to send chaplains who would establish an 'effective Church', and thereby 'a well ordered and morally unassailable Protestant society'. ${ }^{90}$ In doing so, the company believed, the chaplains would counter the behaviour of its personnel, who were 'dangerously disordering themselves with drink and whores'. ${ }^{91}$ Accounts of drunkenness and debauchery amongst the company's personnel were frequent and of serious concern to the company business and image. Personnel across the company, from chaplains to captains, and merchants to governors, expressed concerns about the difficulty of governing such an irregular and almost incorrigible scum of rascals'. ${ }^{92}$ Their main concern about the 'ungodly behaviour' of personnel was the prejudicial effect that it had upon their commercial aims, as it damaged the company's image and reputation amongst the local population. ${ }^{93}$ This did not mean that the company advocated segregation between Englishmen and local populations, as this was considered prejudicial to commercial success. However, 'debauchery' through visiting brothels and drunkenness was perceived to be harmful to integration between the company and local society, and consequently trade.

For both companies, one of the primary methods of group contact was through church attendance and functions such as the sermon. By 1612, the EIC made daily religious communion compulsory, with the factor or captain assembling their 'men or company to hear divine service' every morning and evening. ${ }^{94}$ Although the objective of the chaplains' sermons was primarily for religious worship, they also served to bring together company personnel. At these meetings, not only were men and women told how to behave, but they also served to ensure that the factors, chief merchants and captains were able to meet with those under their authority twice a day. Even though the influence of these meetings is hard to quantify, the company's leadership considered church sermons and attendance an effective method of social control that ensured a way to achieve commercial, and ultimately religious, success. In 1614, David Middleton

90 Stern, Company-State, pp. 117-118.

${ }^{91}$ Letter from Bantam quoted in John Keay, The Honourable Company: History of the English East India Company (London: Harper Collins, 1991), p. 48.

92 Captain Pring to East India Company, March 23, 1619, CSP East, p. 264.

93 Ibid.

94 Foster, Thomas Best, p. 95. 
received a commission that ordered prayers to be read morning and evening, both on land and at sea, ruling that only in the event of sickness could these group meetings be missed. ${ }^{95}$ The company leadership even dictated that group religious observation be held on a household level. A 1615 order declared that good government in the household could be established by 'observing due times of common prayer' and directing that in this way 'servants be kept from disorderly gadding to rack houses, etc. ${ }^{96}$ By providing the company's personnel with a sermon that reinforced the religious governance of the company, the chaplain was benefiting the company but providing 'strong meat, for all growing Christians'. ${ }^{97}$ Thus the chaplain fulfilled his two roles, spiritual to the religious lives of the companies' Protestant employees, and temporal by reinforcing the authority of the EIC and LC. Through sermons and enforcing religious governance, the chaplain was seen to be not only leading his flock towards godliness, but also ensuring the company's goals.

Chaplains themselves were not immune to accusations of placing the company's goals at risk through bad behaviour. Despite the rigorous procedure for picking the right candidate, company officials abroad did often report back that the wrong choice had been made. ${ }^{98}$ On one occasion, an EIC factor, Thomas Kerridge, complained that the chaplain, Peter Rogers, was causing unrest amongst the company personnel at Ajmer. For Kerridge, the role of the chaplain was to 'persuade to peace' rather than 'aggravate wrath'. 99 However, Kerridge accused Rogers of committing the latter, leading him to question Rogers's education and character, suggesting that the 'friends that sent him hither were mistaken in him' 100 On a separate occasion, Patrick Copland complained of another such chaplain's behaviour, recounting the story in a letter to the governor. He wrote that this fellow chaplain, Mr. Goulding, had gone ashore 'after them women', despite being 'expressly forbidden by the

95 Commission to David Midelton, March 12, 1614, in Foster, Letters Received, III: p. 57.

96 A Court of Merchants Held in Siam, April 20, 1615, in Foster, Letters Received, III: p. 108.

97 Terry, Voyage, p. 463.

98 BL IOR B/9 October 20, 29, November 3, 26, December 3, 5, 22, 1624.

99 Thomas Kerridge in Ajmer to Sir Thomas Smyth, March 26, 1615, Foster, Letters Received, III: p. 92.

100 Ibid. 
commander'. ${ }^{101}$ Copland then 'beseeche[d] the Company to send honest preachers' complaining that if they couldn't find good preachers, 'send none', as, he asked, 'How can they work faithfully in the factories when they are dissolute themselves?'102 The LC faced similar problems, with chaplains sometimes being at the heart of, or even fuelling, confrontation whilst abroad. One remarkable case involved a feud between the ambassador at Constantinople, Sir Thomas Glover, and his predecessor, Henry Lello, over when the latter was to end his tenure. The conflict quickly escalated, and at the heart of it was the chaplain, William Biddulph. As a long-time supporter of Lello, Biddulph was disliked by many in Glover's camp, in particular the company agent John Sanderson, who complained of Biddulph's 'lying extolling of Sir Lello'. ${ }^{103}$ Glover himself wrote scathingly of Biddulph, comparing him disparagingly to a Muslim jurist: 'William Biddulph, whom the Turks here call my Mufti, as in deed he is more factious then Mufti, or the Devil himself' ${ }^{104}$ On two occasions certainly, Biddulph, through his contacts both in the Levant and in England, spread scandalous rumours to discredit Glover, including accusations of murder and bigamy. ${ }^{105}$ Despite Biddulph's best efforts, Glover remained ambassador to the Ottoman court till 1611. However, Biddulph's behaviour once again highlights the influence the chaplain wielded in securing, or in this case upsetting, the company's governance abroad. Although the stories of rogue chaplains raise questions as to the bearing of corporate orders on what was happening on the ground, they also reinforce the important position chaplains were placed in. Their behaviour and influence had not only the ability to secure the company's pastoral governance abroad, but also to place it in jeopardy along with the company's reputation.

The chaplain had several methods at his disposal to ensure the good behaviour of the company's personnel and that the companies' religious

101 Copland to Sir Thomas Smyth March 4, 1618 on the Royal James, CSP East, pp. 135-136.

102 Ibid.

103 Quoted in Maclean, The Rise of Oriental Travel, p. 62.

104 Glover to Cecil, April 16, 1607, TNA SP 97/5, f .142.

105 On accusations of murder of company servant, George Coxden, 'Biddulph to 'Mrs. Gratzwicke', July 14, 1607, TNA SP 97/5, f.181; Maclean, Oriental Travel, p. 58; for accusation of bigamy, see, William Biddulph, The Travels of Certain Englishmen, pp. 8081 . 
governance and authority were maintained. Both aboard ships and ashore, the chaplain was paid more than the ship's surgeon and allowed to invest financially in ventures; their standing was in the upper-middle tiers of the company. ${ }^{106}$ EIC chaplains' wages very quickly doubled in the early years of the company's existence, to $£ 100$, and often included substantial supplements for financial provision. ${ }^{107}$ They on occasions would also accompany EIC officials and be present at functions, to advise and lead when needed. At all official functions, Roe was accompanied by a chaplain, throughout his time as ambassador at the Mughal Court. ${ }^{108}$ Roe was reported to have been inconsolable at the loss when his first chaplain Thomas Hall died, writing that he could enjoy 'no Comfort, no conversation' following Hall's passing. ${ }^{109}$ So devastated was Roe at the loss of his confidant and adviser that he wrote he would 'live the life of an Atheist' until a replacement was sent. ${ }^{110}$ On another occasion, the EIC directors turned to Copland, a chaplain whom they greatly respected, to seek advice on the conduct of the captain of the fleet. ${ }^{111}$ Like the personal relationship between Roe and his chaplain, the EIC leadership's reliance on Copland further demonstrated the power and influence of a chaplain. Copland wrote back to the court, commending the 'zeal and care' shown by Captain Best in establishing 'good government amongst his people, which maintained love between them, living peaceably and conscionable all the whole voyage'. ${ }^{112}$ Chaplains were important not only to establish the companies' own religious governance, but were also instrumental in legitimising and bolstering the authority of other members of the company.

106 For the ability and incidence of chaplains adventuring in the EIC, see BL IOR B $/ 5$ A Court of Committee June 29, 1614; for LC incidents particularly involving Robert Frampton, see ToNA SP 105/175 f. 13, 26, 113, 132, 150.

107 CSP East, February 9, 1607; BL IOR B/5 A Court Committee, October 26, 1614.

108 For the role of Jesuit ministers at the Mughal Court, see João Melo, 'Seeking Prestige and Survival: Gift-exchange Practices between the Portuguese Estado da Índia and Asian Rulers', Journal of the Economic and Social History of the Orient, Vol. 56 (2013), pp. 672-695.

109 August 19, 1616, in Foster, Embassy of Thomas Roe, I: p. 245.

110 Ibid, p. 246.

111 Story recounted in O'Connor, Chaplains, p. 38.

112 Copland to Court of Directors, June 9, 1614, Extract from the Court Minutes of the EIC, Vol. III, in Foster, Thomas Best, p. 264. 
As a group, chaplains were an instrumental body in the companies' aim to establish pastoral governance abroad. However, it was often the work of individual chaplains that made the biggest impression on how the companies' missions would evolve. One of the most frequently mentioned chaplains in the early history of the EIC is Patrick Copland. Originally a graduate from the University of St. Andrews, Copland, a Scottish Episcopalian, was asked by the company to serve on four voyages between 1612 and 1621, before leaving for Bermuda and becoming a Congregationalist. ${ }^{113}$ Copland is mostly remembered in the history of the EIC for instigating the first company conversion of a Bengali boy in 1614 . Returning from India that year with the boy, Copland managed to arrange for the EIC to provide a stipend for the boy to attend school in London, where he was to be 'taught and instructed in religion'. ${ }^{114}$ Just as with the VC, Copland and the EIC hoped that by educating the child he would convert and 'might upon occasion bee sent into his country' and whilst there 'God may be so pleased to make him an instrument in rounding some of his nation'. ${ }^{115}$ One year later, Copland reported back on the success of the boy's education, proclaiming him to have 'profited in the knowledge of the Christian religion' and that it may benefit the company to hold a baptism 'publicly' as he was amongst the 'first fruits of India'. 116 After some discussion with Maurice Abbot's brother, the Archbishop of Canterbury, the company agreed. The following December, the boy was baptised at the Church of St. Dionis in front of a congregation made up of the Privy Council, Lord Mayor, Aldermen and members of the EIC and VC. ${ }^{117}$ The King himself chose the boy's name as Peter Pope, in what Edward Neill described as 'that odd compound of cant, coarseness, and Scottishness'-or possibly just humour. ${ }^{118}$ Following the public successes of this early attempt at pastoral governance and evangelism, Copland and Pope returned to the East, where Pope, still under the tutelage of Copland, would continue his education and even write back to the

113 Edward D. Neill, Patrick Copland, pp. 90-93.

114 BL IOR B/5 A Court Committee, August 19, 1614; Neill, Memoir of Rev. Patrick Copland, pp. 13-14; Foster. Thomas Best, p. xx.

115 BL IOR B/5 A Court Committee, August 19, 1614.

116 BL IOR B/5 A Court Committee, July 18, 1615.

117 Neill, Patrick Copland, p. 12; Copland and Pope, Virginia's God Be Thanked.

118 Copland and Pope, Virginia's God Be Thanked. 
company. ${ }^{119}$ Some years later, Copland and Pope returned to England to obtain support for yet another of Copland's education projects in Virginia. Having, on a return voyage from the East, heard that there was a lack of schools in Virginia, Copland embarked on a campaign to raise funds to establish a school in Virginia. Its purpose was to educate, like Pope, Native American children, 'in the principles of Religion, civility of life, and humane learning' ${ }^{120}$ Copland was successful in his mission of obtaining company support, initially managing to persuade 142 EIC employees to pledge donations for the opening of the East India School in the colony, although the plan would be aborted following the massacre in 1622. ${ }^{121}$ Despite his successful relationship with the company, Copland did face criticism. Following the battle of Jakarta, his sermon was accused of being so influential that he 'dissanimated' the sailors, who refused to fight against the Dutch, their fellow Protestants. ${ }^{122}$ However, for the most part Copland can be seen as one of the companies' most successful early chaplains, firmly establishing and connecting pastoral governance and its passive proselytism in the early English companies, across both the Atlantic and Indian oceans.

The cosmopolitan nature of business in both Turkey and India meant that EIC and LC personnel were forced to mingle with a number of different religious groups. The strangers accounts for the LC at Constantinople highlight this diversity, listing business dealings with Jews, Muslims, Orthodox Armenians, Orthodox Greeks, Protestant Dutch, Catholic French and Venetians. ${ }^{123}$ Similarly, in India, EIC personnel entered a business environment that was religiously diverse. ${ }^{124}$ For both

119 Ibid.

120 Copland, A Declaration How the Monies (Viz. Seventy Pound Eight Shillings Sixe Pence) Were Disposed Which Was Gathered (by M. Patrick Copland, Preacher in the Royall Lames) at the Cape of Good Hope (Towards the Building of a Free Schoole in Virginia) of the Gentlemen and Mariners in the Said Ship: A List of Whose Names Are Under Specified, for Gods Glory, Their Comfort, and the Incouragement of Others to the Furthering of the Same, or the Like Pious Worke (London: 1622).

121 Ibid.

122 Copland to Court of Directors, June 9, 1614, Extract from the Court Minutes of the EIC, Vol. III, in Foster, Embassy of Thomas Roe, p. 264.

123 TNA SP. 105/109, f. 149, 189.

124 BL IOR/B/11, January 5, 1626/27; William Thurston and Edward Pearce at Basra to the Company, June 22, 1640, Foster, English Factories, II: p. 73; VI: p. 248; Danvers, Letters Received, VI: pp. 244, 303. 
companies, their personnel were forced to interact with individuals and groups of varying faiths to secure the commercial mission of the company. However, these interactions brought with them dangers that the companies' leadership believed their personnel needed to be protected against. EIC and LC officials relied on the chaplains' enforcement of pastoral governance to ensure that their personnel remained, and behaved as, the godly.

From their initial attempts to establish trade abroad, the EIC and LC were wary of the allure other faiths might have on their personnel. The leadership of both companies was conscious of the damaging effects conversion from Protestantism would have on the reputation of the faith, nation and governance of the company. For many, the biggest fear was conversion to Islam. In the Ottoman, Persian and Mughal Empires, conversion not only meant a switch in faith, but also national identity. Edward Terry speculated that the practical appeal of Islam to many Europeans, as well as for those who practised the religion, was the liberty and toleration it afforded towards the marriage rights of men. According to Terry, it was partially this that encouraged apostasy and hindered 'the settlement and growth of Christianity in those parts'. ${ }^{125}$ Marriage posed several problems for the company, which ranged from the legality and religious sanctity of marriage to the issue of the subject identity of not only the couple, but also any children born from the union. Much later, following the Restoration, an English captain was sent out to the North African coast to secure the return of some Englishmen from slavery. However, he reported that the men refused to return and wished to remain Muslim. According to the captain, the reason that these men 'were tempted to forsake their God' was 'for the love of Turkish women, who are generally very beautiful'. ${ }^{126}$ Over the same period, the allure of Muslim women for Christian men, and the threat they posed, was immortalised in English folk song. In the Ballad of Lord Bateman, a noble from Northumberland is captured in Turkey, and whilst imprisoned by an Ottoman governor falls in love with his daughter. Several years after his release, she sails to England and convinces him to abandon

125 Terry, A Voyage, p. 428.

126 Quoted in John B. Wolf, The Barbary Coast: Algiers Under the Turks, 1500 to 1830 (New York, NY: W. W. Norton, 1979), p. 237. 
his Christian bride, to marry her. ${ }^{127}$ Not only were Muslim women seen as exotic and seductive by the religious and political leadership, within and outside the company, their stance on marriage also caused concern. In the European imagination, Islam became highly sexualised as it became increasingly associated with polygamy and the concept of the harem, and the dangers of cultural exposure to this were never far from the minds of the EIC and LC leaders. ${ }^{128}$ However, by providing a minister, company officials hoped to prevent apostasy, ensuring that their personnel remained within the godly and behaved according to the pastoral governance of the company.

Despite the fear of apostasy amongst the companies' English personnel, pastoral governance supported rather than prevented the companies from interacting with and employing people of numerous faiths, many of whom were European converts. The letter books of the EIC report cases that demonstrate how the company was primarily only concerned with the conversion of English subjects, or specifically its own personnel, reinforcing the idea that evangelism, for much of the seventeenth century, was an internal mission. Evangelism was encouraged by example rather than coercion, to not endanger the company's relationship with educated middlemen such as European converts, Jews and Orthodox Armenians, as well as Hindus and Muslims, on whom it relied. One case in the EIC involved a recently employed Portuguese convert to Islam who had become an 'enemy of the Jesuits' and had come into the employ of the factor at Agra, Thomas Kerridge. Worried by his employee's status as a converted European, Kerridge wrote a letter to ensure his continued employment, as he wished to keep him in service, writing that, as a European convert, he did 'more business in an hour than his banyan in a day'. ${ }^{29}$ The prospect of an Englishman in the company committing apostasy continued to be a threat that the companies' spiritual and secular leadership feared. Such news of English converts 'greatly afflicted' the Levant Company, as they feared it would 'draw no mean Scandal to

127 'The Loving Balled of Lord Bateman', in Francis James Child, ed., The English and Scottish Popular Ballads, vols. 10 (New York, NY: Dover Publications, 1884), I: p. 477.

128 Hsu-Ming Teo, Desert Passions: Orientalism and Romance Novels (Austin, TX: University of Texas Press, 2012), pp. 37-50.

129 Thomas Kerridge at Agra to Thomas Aldworth and the Council at Surat, September 7, 1613, in Foster, Letters Received, I: pp. 283-284. 
our nation and to the Christian Religion'. ${ }^{130}$ However, in the case of the EIC and this particular Portuguese convert to Islam, his coming into the employment of the company was not an issue. It was perceived that his apostasy had only brought disgrace to his nation, not the English one, and so was not a threat to the authority of the company.

\section{Chaplains and Knowledge Exchange}

The companies not only companiesrovided the chaplains with employment, but also offered them unique opportunities to take part in commerce and knowledge exchange. Through company employment they were provided with the opportunity to advance their academic and ecclesiastical credentials, which would also develop ideas on religious governance at home and abroad. The expectation that chaplains would establish a religious government, in addition to individual ministers' curiosity about foreign religious cultures, surrounded the experiences of company chaplains in this early period. Being educated men, chaplains were sought after by officials both inside and outside the companies who hoped to utilise their talents, to advance English academic and religious pursuits.

The interactions associated with pastoral governance that chaplains were involved in abroad offered rare opportunities to pursue intellectual pursuits, that advanced their academic and ecclesiastical future at home. By hunting for early Islamic and biblical manuscripts or penning works on their travels, chaplains became key figures in an exchange of knowledge across oceans. Of a long line of influential LC chaplains who effected religious and academic governance abroad and in England, one of the most famous was the Middle Eastern scholar and the first Laudian Chair of Arabic at Oxford, Edward Pococke. ${ }^{131}$

130 TNA SP. $105 / 113$, f. 188.

131 Mills, 'The Chaplains to the English Levant Company: Exploration and Biblical Scholarship in the Seventeenth and Eighteenth-Century England', in Judith Becker and Bettina Braun, eds., Die Begegnung mit Fremden und das Geschichtsbewusstein (Gottingen: 2012), pp. 243-266; Mills, 'The English Chaplains at Aleppo: Exploration and Scholarship between England and the Ottoman Empire, 1620-1760', Bulletin of the Council of British Research on the Levant, Vol. 6, No. 1 (2011), pp. 13-20; Smith, 'Risky Business', pp. 244245; G. J. Toomer, Eastern Wisedome and Learning: The Study of Arabic in Seventeenth Century England (Oxford: Oxford University Press, 1996), pp. 116-225. 
Born in Oxford in 1604, Pococke was the eldest son of Edward Pococke, a clergyman and one time fellow at St. Mary Magdalen college. After attending a free school in Thame, Oxfordshire, Pococke entered Magdalen Hall in 1618, following which in 1620 he received a scholar's place at Corpus Christi College, Oxford. ${ }^{132}$ In 1622, at the age of 18, he was admitted to the degree of Bachelor of Arts, where his interest in Middle Eastern languages was sparked by his tutors, the German exile mathematician and Hebrew, Arabic and Syriac scholar Matthias Pasor and the influential English Arabist and religious minister William Bedwell. ${ }^{133}$ Pococke graduated at the age of 26 and that same year applied to fill the vacant chaplaincy position, following fellow Oxford graduate Charles Robson's return to England from the Levant. ${ }^{134}$ Many years later noted polymath John Selden received a recommendation from the English consul describing him as 'a diligent and able gent' and that his skills as a translator were such that 'he himself made Arab his mistress'. ${ }^{135}$ Convinced that Pococke's skills as both theologian and translator made him right for the job, Selden concluded, 'I shall intreate you to accept from me', yet despite being the only applicant, Pococke was forced to go through the rigmarole of selection. ${ }^{136} \mathrm{He}$ was finally selected by the company in March 1630, after the company received further 'very good testimony \& recommendations'. ${ }^{137}$ Moreover, they commended Pococke's 'ability in learning, Soundness in the Study of divinity, conformity to the constitutions of the Church \& integrity of Life and conversation'. ${ }^{138}$ Although Pococke was a capable chaplain, it was not in his spiritual role that he achieved fame, instead receiving recognition both during his time in the Levant and after for his notable achievements as an agent of knowledge exchange and oriental learning.

By the middle of October 1630, Pococke had arrived in Aleppo and immediately set to work amassing a substantial collection of oriental manuscripts, many of which he would translate and send back to England

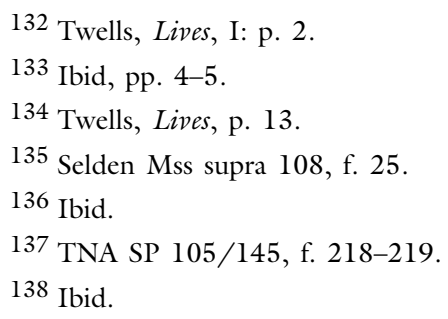


to William Laud, who was then Archbishop of London and the Chancellor of Oxford. ${ }^{139}$ Although possibly not the main reason behind Pococke's interest, these manuscripts were part of Laud's desire to mould the established Church's governance by reconnecting the Church with its eastern counterpart, the Greek Orthodox Church. According to Laud, the English Church was 'an Orthodox Church' and being so, he believed that it was perfectly lawful to communicate with other Orthodox churches. ${ }^{140}$ Communications between the Greek and English Churches had been established by Laud's predecessor, George Abbot, and were continued under him. ${ }^{141}$ As early as 1631, Laud wrote to Pococke requesting that he send back manuscripts to build up the library at Oxford, and several years later Laud wrote a letter to the LC directly ordering that every company boat return home 'one Arab, or Persian Manuscript Book', which would be delivered to him. ${ }^{142}$ Although the company may have been fairly relaxed about sending material back to England, Pococke was not. Many of the early manuscripts in the Bodleian library either were acquisitions made by Pococke on behalf of the library or for his private collection. ${ }^{143}$ This includes over 400 Arabic, Hebrew, Persian, Turkish, Greek and Armenian manuscripts that cover a variety of subjects, from history to literature and religion to philology.

In both the acquiring of manuscripts and learning of languages, Pococke was helped by building a substantial network of friendships with European and Ottoman scholars, clergymen and merchants of varying

139 Mills, Commerce of Knowledge, pp. 71-72; Twells, Lives, pp. 6-7.

140 William Laud, A Relation of the Conference Between William Laud Late Lord Archbishop of Canterbury and Mr. Fisher The Jesuit (London: 1673), pp. 243.

${ }^{141}$ For the relationship between Abbot, Laud and Lucaris, see Steven Runciman, The Great Church in Captivity: A Study of the Patriarchate of Constantinople from the Eve of the Turkish Conquest to the Greek War of Independence (Cambridge: Cambridge University Press, 1968), pp. 294-296; For more on the relationship between Cyril Lucaris, Orthodoxy, the Anglican Church and religious governance in England, see W. B. Patterson, 'Cyril Lukaris, George Abbot, James VI and I, and the Beginning of Orthodox-Anglican Relations', and Colin Davey, 'Metrophanes Kritopoulos and his Studes at Balliol College from 1617 to 1622', in Peter M. Doll, ed., Anglicanism and Orthodoxy: 300 Years After the 'Greek College' in Oxford (Bern: Peter Lang, 2006), pp. 39-78.

142 TNA SP 16.260, f. 116.

143 Mills, Commerce of Knowledge, p. 71. 
faiths, many of whom he stayed in contact with until the end of his life. ${ }^{144}$ Pococke was particularly keen to improve his written and spoken language skills, and employed a number of individuals to aid him. ${ }^{145}$ Of all his language studies, it was to Arabic that Pococke dedicated most of his spare time. Whilst in Aleppo, he employed a native speaker named Hamīd as his personnel attendant, in order to acquire a better knowledge of the spoken language, whilst he became acquainted with a Muslim 'shaykh' to improve his reading and writing. ${ }^{146}$ Writing from Aleppo in 1671, then LC chaplain and fellow orientalist Robert Huntington informed Pococke that his 'old scheich' had died several years earlier, but that he still fondly remembered him even on his deathbed, declaring that 'he did not doubt but to meet you in paradise, under the banner of our Jesus'. ${ }^{147} \mathrm{Simi}^{-}$ larly, during his time in Aleppo, Pococke employed a number of Jewish instructors, including a Rabbi to teach him Hebrew. Likewise, during his time in Constantinople Pococke employed a number of Jews, including Jacob Roman, to help him in his academic and personal pursuits. ${ }^{148}$ It is particularly noteworthy that Pococke enjoyed conversing with Roman about the various Christian sects and the theological differences he had observed when reading about their beliefs. ${ }^{149}$

In addition to Roman, Hamīd and his 'old scheich', Pococke also formed intellectual friendships and maintained contacts with a number of Christians, including Dutch Orientalist Jacobus Golius and his brother, the Carmelite friar Petrus Golius, as well as leaders of the Greek Orthodox

144 Claire Gallien, 'Orientalist Pococke: Brokering across Borders, Disciplines and Genres', in Robert Mankin, ed., The Internationalization of Intellectual Exchange in a Globalizing Europe 1636-1780 (Lewisburg, PA: Bucknell University Press, 2017), pp. 130; For information on trans-cultural or trans-imperial agents and brokers see E. Natalie Rothman, Brokering Empire: Trans-Imperial Subjects between Venice and Istanbul (Ithaca, NY: Cornell University Press, 2012), pp. 3-7, 36-38.

145 Toomer, Eastern Wisedome, p. 121.

146 Mills, 'Learning Arabic in the Overseas Factories: The Case of the English', in Jan Loop, Alastair Hamilton and Charles Burnett, eds., The Teaching and learning of Arabic in Early Modern Europe (Leiden, Brill, 2017) p. 280.

147 Quoted in Twells, Lives, pp. 30-31.

148 Pococke, 'Porta Mosis' in Twells, Theological Works, p. 160; Toomer, Eastern Wisedome, p. 121; Mills, Commerce of Knowledge, p. 90.

149 Twells, Lives, p. 46. 
Church. ${ }^{150}$ These included the Patriarch Cyril Lucaris, whom Pococke's eighteenth-century biographer described as having 'a great esteem for Mr. Pococke', and Nathaniel Canopius. Following the death of the former, the latter fled to England and studied at Balliol College, where, it is rumoured, he was the first person to introduce coffee drinking to England, a habit Pococke would also be known for in Oxford. ${ }^{151}$ Through these friendships, Pococke engaged in a series of transcultural exchanges that allowed him to pursue his studies in not only Middle Eastern languages, but also history, culture, law and faith. Moreover, and no less important, they also provided him with further contacts to establish and nourish links with local merchants and collectors whom he could call upon to acquire the many manuscripts he sought, both whilst in the Levant and after he returned home.

Although these friendships arose from a transactional relationship, they were often just as deep and as long-lasting as the others that Pococke formed whilst in the Levant. Again, as in his academic pursuits, these crossed the various ethnic, religious and cultural divides of the Levantine world, including Muslims, Greek and Syriac Christians, Jews and European travellers. One such collector whom Pococke used to acquire manuscripts was the German itinerant minister and orientalist Christianus Ravius. A transcultural European, Ravius travelled throughout Europe and the Middle East between 1636 and 1677. Before travelling to the Ottoman Empire, he studied at Oxford, where through his friendship with Pococke he secured free quarters at the English Embassy in Constantinople. There, Pococke wrote, he saw it 'very fitting' that Ravius 'be employed in setting forth of books in the Arabic Language'. ${ }^{152}$ Ravius would later return to Oxford to teach Hebrew, before lecturing in Upsala, Kiel and Frankfurt an der Oder. In his quest for oriental manuscripts, Pococke also developed close friendships with a Greek surgeon called Georgio Cergio, a Syrian Christian named Abdel Messiah and Michael Thaljah, the scribe and brother of a local Greek Bishop. ${ }^{153}$ Yet it was his

150 Although Pococke was in contact with Jacobus Golius, he had left Aleppo by the time Pococke had arrived: Toomer, Eastern Wisedome, pp. 120-122; Twells, Lives, pp. 23, 300.

151 Judith Pinnington, Anglicans and Orthodox: Unity and Subversion 1559-1725 (Leominster: Herefordshire; Gracewing, 2003), p. 15.

152 Twells, Lives, p. 61.

153 Twells, Lives, pp. 56, 58; Gallien, 'Orientalist Pococke', p. 22. 
friendship with a Muslim scribe and scholar, who would be his teacher, from Aleppo named Darwish Ahmed ibn Husam al-Gulshani that has become the most enduring representation of the transcultural friendship network that made up Pococke's collectors. ${ }^{154}$

Although not dated, it has been proved that five letters were sent between 1636 and 1640, after Pococke's return to England, and they are a testament to the friendship of both Pococke and al-Gulshani. ${ }^{155} \mathrm{Al}$ Gulshani details the manuscripts sent from Aleppo and Oxford, which he had collected and purchased for Pococke. These included among others a copy of an encyclopaedia produced by a Muslim secret society, a twelfthcentury work on agricultural practices called the Kitāb al-filāha, an Egyptian zoological text entitled Hayāt al-hayawān, an Arabic adaptation of Indian fables called the Kalilah wa-Dimnah, as well as countless biographies, commentaries and religious texts. ${ }^{156}$ Occasionally, the letters also highlight the transactional nature of transcultural knowledge exchange, with al-Gulshani on one occasion requesting Pococke send him 'something of the rarities of your homeland' and a 'printed geography'. ${ }^{157}$ To add to the detailed notes of the manuscripts exchanging hands, alGulshani's letters show the close bond between himself and Pococke, addressing the chaplain in several letters as his 'dear pupil', whilst also detailing significant events in his life such as his marriage. ${ }^{158} \mathrm{Al}$-Gulshani's letters also note how he kept up to date on events in Pococke's life, describing him after he had taken the chair in Arabic as 'the teacher of the English sect, the erudite in Christian sciences, and the researcher into the roots of the Arabic language'. ${ }^{159}$ Yet it is from his letter following the

154 Gallien, 'Orientalist Pococke', p. 11; see Simon Mills's incredible work on Pococke in the Levant and his relationship with Gulshani, in particular his role as his Arabic tutor, as well as the Gulshani's important role in acquiring large numbers of manuscripts for Pococke: Mills, Commerce of Knowledge, pp. 74-89; Hilary Kilpatrick, 'Arabic Private Correspondence from Seventeenth-Century Syria: The Letters Edward Pococke', Bodleian Library Record, Vol. 21, No.1 (2010), pp. 20-40; P. M. Holt, Studies in the history of the Near East (Abingdon, Oxford; Frank Cass, 1973), pp. 3-66; Toomer, Eastern Wisedome, pp. 222-223.

155 Five letters have been translated in Holt, Near East: see Appendix II, pp. 42-45.

156 Holt, Near East, p. 42-45; Mills, Commerce of Knowledge, p. 78.

157 Ibid, p. 43.

158 Ibid, pp. 42-43.

159 Ibid, p. 43. 
death of Pococke's father in 1636/7 that we gain a touching insight into the enduring bond between these two men. The letter consists of several condolences, and Pococke is affectionately addressed by al-Gulshani as his 'honoured and dear son'. ${ }^{160}$ Moreover, he often asked Pococke to inform him of events in his life, requesting on one occasion that he 'send me a letter in the Arabic tongue, and send also without fail to inform me of your condition'. ${ }^{161}$ By travelling, Pococke was not only able to acquire manuscripts and advance his own language learning, but also establish a network of friendships that were truly transcultural, transcending the cultural, linguistic and religious divides of the time.

Apart from the acquisition of manuscripts, these friendships helped Pococke advance his own scholarly learning, furthering his understanding of Arabic, Syriac, Ethiopic and Hebrew languages. Despite returning to Oxford in 1636 and obtaining a post at the university, Pococke was only home a mere two years before asking to be returned to the Levant. Obtaining the support of Laud, Pococke returned to the Middle East, still in receipt of his academic salary and with permission from the company to supplement his salary by trading in bales of cloth. ${ }^{162}$ During this second Eastern sojourn, Pococke not only continued to amass and send home manuscripts, but also fulfilled the influential and important duty of chaplain to two ambassadors. By $1639 / 40$, Pococke had returned permanently to England and continued his academic career, translating, annotating and publishing numerous oriental manuscripts in Latin for a European audience that was increasingly interested in learning about the culture, law and history of the Islamic world. Some of the texts Pococke translated included works by Eutychius, a short account of the origin and manners of the Arabs, the preface to an Arabic version of the Pentateuch, a complete Arabic edition of Bar Hebraeus' work and what has been described as both his 'masterpiece' and 'magnum opus', the Specimen historiae arabum (collected for him by al-Gulshani). ${ }^{163}$ These texts were part of the transcultural expansion of seventeenth-century learning; as commerce encouraged English culinary tastes and fashions to change,

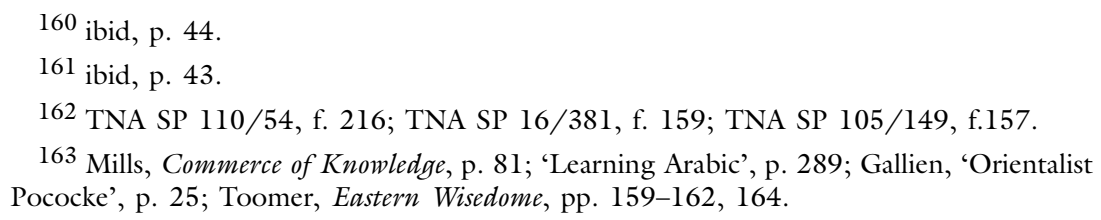


it also encouraged English intellectuals to learn about the cultures and peoples that they were trading with. Furthermore, the surge in language learning also inspired the exportation of European culture, and religion, in the form of the Polyglot Bible. Pococke actively assisted in its production and compilation, specifically the sections in Arabic, and was so connected with its development that it was first mentioned in a letter between Selden and Pococke in 1652. ${ }^{164}$ Although his employment in the LC was essential in developing his knowledge of Middle Eastern language and culture, it did not guarantee him support following his exit from the company's employment. Despite having a tradition of funding religious educational initiatives such as the translation of the Bible into Turkish, Pococke did not receive any financial or institutional support from the LC. ${ }^{165}$

Through the LC, Pococke enhanced his scholarship, acquired manuscripts, interacted with peoples of numerous faiths and experienced the pastoral governance of the company. The experiences granted him influence in both the Church and academy in England, and through his work and connections the company could mould, for a period, their own governance. Pococke highlights the role overseas chaplains would play in developing and governing varying institutions when they returned to England.

As in the Ottoman Empire, India offered chaplains similar possibilities to influence the direction of governance and expansion both at home and abroad through academic pursuits. One EIC chaplain who sought to influence the pastoral governance of the company, alongside opinions and ideas of Indian peoples in England, through the knowledge he acquired whilst working for the company, was Henry Lord. Before leaving India, Lord sent his manuscript back to England and upon his return published an account of his interactions with the Hindu and Parsi faiths that he had encountered when out there. Published the same year that Pococke left for Aleppo, Lord's $A$ display of two forraigne sects offered one of the first in-depth English language analyses of the two religions. ${ }^{166}$

164 Toomer, Eastern Wisedome, p. 203; part of the letter can be found in Twells, Lives, p. 205.

165 W. Seaman to Boyle 5 October, 1664, BC, II: pp. 341-342; W. Seaman to Boyle, 19 October, 1664, BC, II: pp. 353-354; Mills, Commerce of Knowledge, p. 212.

166 Lord, A Display of Two Forraigne Sects; O' Connor, Chaplains, pp. 68-69. 
A display of two forraigne sects can be considered to have established a new genre of literature in the Protestant world that would later include Abraham Roger's De open-deure tot het verborgen heydendom (1651) and Bartholomaus Ziegenbalg's Genealogie der Malabarischen Gotter (1713). ${ }^{167}$ Lord's work was unique in English literature, considering its focus was solely on religion, whereas earlier works had only mentioned religion as a part of sections on customs and practices in the region. Christopher Farewell's An East-India Coalition (1633) and Edward Terry's sympathetic account Voyage to East India (1655) reported on religion but were much more interested in broader political and social descriptions of India and its peoples. Terry in his famous account held a mirror up to his readers, encouraging reflection on the conduct of the English in foreign lands, in comparison to the behaviour of the Indians. One of his aims was to illustrate how commercial or spiritual agendas could only be achieved when English travellers and company personnel 'as the Beams of the Sun put forth their virtue, and do good by their reflection'. ${ }^{168}$ Discussing several attributes, in his reflection Terry criticises the Christian behaviour of EIC personnel, writing how 'we quarrel at the superstition and blind devotion of others. But let us examine ourselves, whether superstition in them, hath not a great deal of more heat in it, than Religion in us'. ${ }^{169}$ For Terry, evangelism was an important goal, that could only be achieved when the temporal and spiritual behaviour of the English had been rectified. His work aimed to instruct the reader, both by example and reflection upon local Indian customs, highlighting the importance of behaviour in evangelism. ${ }^{170}$ Lord, on the other hand, was simply critical of the lack of evangelism, not finding fault in the daily behaviour of English personnel in India, but in the lack of zeal in their attempts to evangelise. In order to rectify this, Lord sought to inform his English audience of 'the inner secrets of an ancient people' by viewing the religious practices and customs of groups of Hindus, Jains

167 Xavier and Županov, Catholic Orientalism, pp. 115-244.

168 Terry, A Voyage, p. 453.

169 Ibid, pp. 441-442.

170 Ibid, pp. $452-545$. 
and Parsees in India through a Christian viewing glass. ${ }^{171}$ This was a form of 'paganopapism' used by Lord to find a connection between Indian faiths and Roman Catholicism in order to criticise both the former and the latter. ${ }^{172}$ This includes presenting religious texts as the 'Banian Bible', suggesting Pourous (Purusha) and Parcoutee (Prakriti) lived together like Adam and Eve and his description of a creation myth paralleling that in Genesis. ${ }^{173}$ Lord distorts the customs, laws and origins of local Indian religions in order to justify his agenda, emphasising Indian people's 'heathenism' as well as presenting the similarities to Christianity as a means to highlight the potential for conversion.

Little is known about Lord. It has been argued that he was born in 1563 and attended Magdalen Hall, Oxford, although this would have meant that he would have been 61 when appointed to the EIC in 1624, at a time when the average age of these early ministers was $30 .{ }^{174}$ However, Nora Firby has argued that Lord was older, suggesting that he was 63 when he entered the company's service, and that the company made the decision to send out an older man due to a series of incidents involving younger ministers. ${ }^{175}$ Moreover, Lord came highly recommended, with the company minute noting how the 'court had particular commendation of Mr Lord from Mr Deane White under whom he served as Curate, and likewise from Mr Shute'. ${ }^{176}$ Lord from the beginning of his company career had openly expressed an interest in evangelism. His interview sermon, which was taken from Ephesians 5:11, 'Have no fellowship with the works of darkness but rather reprove them', neatly summarises the

171 Amrita Sen and Jyotsna G. Singh, 'Classifying the Natives in Early Modern Ethnographies: Henry Lord's A Display of Two Foreign Sects in the East Indies (1630)', Journeys, Vol. 14, No. 2 (2013), p. 74.

172 Nora Firby, European Travellers and their Perceptions of Zoroastrians in the Seventeenth and Eighteenth Centuries (Berlin: Dietrich Reimer, 1988), pp. 110-111.

173 Lord, A Display of Two Forraigne Sects, p. 4; Sen and Singh, 'Classifying the Natives', pp. 75-76.

174 Will Sweetman, Mapping Hinduism: 'Hinduism' and the Study of Indian Religions, 1600-1776 (Halle: Verlag der Franckeschen Stiftungen zu Halle, 2003), pp. 65-66; Firby, European Travellers.

175 Firby, European Travellers, p. 98.

176 BL IOR B/8 A Court of Committees held of the January 7, 1624. 
rationale behind his later work, both to reprove the intellectual ignorance of the English and the spiritual iniquity of the Indians. ${ }^{177}$

Despite never straying far from Surat whilst in India, Lord's time in the city offered him considerable opportunity to investigate and learn about the faiths that he encountered. Lord's story began in the city in 1624, having successfully imposed the company's pastoral governance on board a ship in 'gain[ing] a charge of souls in the Adventure of the honourable Company of Merchants trading to the East-Indies'. ${ }^{178}$ Even as he mentions his success in establishing and securing religious governance aboard the EIC's ships, several biblical verses on the ornate frontispiece of his work set the tone for the reasoning behind its publication. The verses that Lord used express two related concerns of his book: firstly, his (albeit prejudiced) interests in the religion and governance of the Hindu and Parsi people, and secondly how to 'reform' their religious governance. The first verse from 1 Corinthians 11:19, 'For there must be heresies even among you, that they which are approved among you, might be known', expressed Lord's wish to inform his readers of Indian religions. The second, taken from Isaiah 9:16, 'For the leaders of the people cause them to erre: and they that are led to them are destroyed' reinforced his perception of English spiritual superiority and encouraged the company and English people back home to support evangelism. ${ }^{179}$ Whether or not his work was well received by the company, Lord sought to provide knowledge to help the process of establishing the company's 'reforming' religious governance in India.

By explaining the creation myths, holy texts, eating habits and the traditions governing the social structures of the Hindu and Pars Parsi i religions, Lord sought to inform his readers so they could judge and, as with all judgements, a sentence for reform would follow. According to Lord, the two faiths were 'rebelliously and schismatically violating the divine law of the dread Majesty of Heaven', and so required his readers, in particular the Archbishop of Canterbury, to whom the book was dedicated, to 'judge of their causes and crimes'. ${ }^{180}$ Despite his own religious sentiments, Lord does seem to fondly recall his interaction with Indian

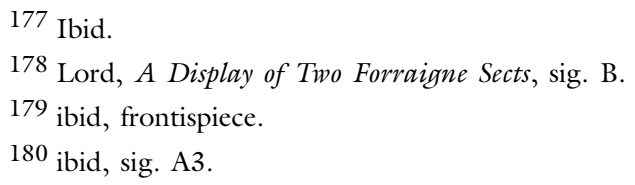

177 Ibid.

178 Lord, A Display of Two Forraigne Sects, sig. B.

179 ibid, frontispiece.

180 ibid, sig. A3. 
peoples, notably his first encounter with a Hindu. He gives an account of a Hindu man who worked for the company, noting his 'linen garments' and 'gesture and garb as I may say maidenly and well-nigh effeminate', concluding, with a note of fondness, how the people were 'strangely notable, and notably strange?"181 Throughout, Lord seeks to compare and criticise elements of the Hindu and Parsi religious governance by comparison with historical comments and biblical and Christian teachings. In his discussion about Hindu laws, in particular the prohibition on the drinking of alcohol and eating of meat that he particularly criticises, Lord argues that both were part of a 'tradition' that was 'void of ground or reason'. ${ }^{182}$ According to Lord, the Romans described ancient Indians as 'vini amatores, lovers of Wine', highlighting the classical misconceptions many English travellers held. At the same time, Lord also called upon his Christian understanding of the world to suggest that the practice of not eating meat was 'against the common end and use of the Creature, which God hath made to comfort the heart of Man' ${ }^{183}$ For Lord, the Hindu practice of vegetarianism was a problem, as they rejected God's purpose in creating animals, but was also easily rectified through Christian scripture, and as such by the successful establishment of pastoral governance. Similarly, Lord tried to establish the societal structure of India through their religious governance, discussing caste and how society was ordered, noting, particularly, the Brahmins who 'instruct people in matters of Religion'. ${ }^{184}$

Lord concludes his remarks on the religious governance in India by discussing how 'all evidences of brains intoxicate with the fumes of Error and Polytheism' and deems 'their Religion a composed Fiction, rather than anything real for faith to lean on'. ${ }^{185}$ Not only was Lord making one final pointed remark on the consumption of alcohol in Indian society, but he was also commenting on the role of religion in governance, for since their faith was not real enough to lean on, their government too was weak and so required the establishment of Protestant religious governance to secure this. Although this would not happen as Lord may have wanted,

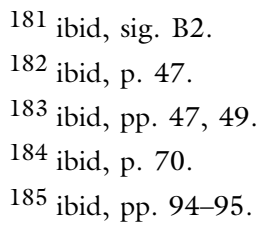


and not until after the post-Braganza era, $A$ display of two forraigne sects illustrates how, in England at least, ideas on the permanence and exportability of pastoral governance were beginning to form through the EIC's early interactions.

\section{Pastoral Governance and Securing Commercial Success and Religious Behaviour}

Although at their core the EIC and LC remained commercial enterprises with profit maximisation as their primary mission, the religious interests of their members ensured that theologically diverse chaplaincy would play a part in the companies' evolution. For the companies to achieve their commercial mission they required their personnel, whether religious or secular, to maintain cordial relations between themselves and the diverse religious and cultural communities that surrounded them. Interactions with other communities, however, not only proved to be a challenge to the commercial enterprise of the companies, but also complicated the religious and commercial life of English communities. Powerful and close-knit religious communities such as the Armenians, who had a deep understanding of Mughal, Safavid and Ottoman religious governance, often proved difficult for the EIC and LC to negotiate in this early period.

Early interactions with the Armenian community in India and Persia illustrate this difficulty and highlight how the pastoral governance of the company could be manipulated to negative effect when dealing with strong religious minorities. In the first few decades of the EIC's existence, the combination of a lack of gold and a weak naval presence in the region hampered relations between company officials who wanted to establish a silk trade and the Armenians who effectively monopolised the trade across Persia and into the Levant. ${ }^{186}$ In 1619, the company council in London recommended to its factors in Isfahan that they send letters with Armenian and Georgian merchants, as they 'travell saufley and freely without superstition betwixt Persia and Turkey'. ${ }^{187}$ Seeing an opportunity, the company in London sought to gain from the expertise of Armenian trade,

186 R W. Ferrier, 'The Armenians and the East India Company in Persia in the Seventeenth and Early Eighteenth Centuries', The Economic History Review, Vol. 26, No. 1 (1973), pp. 43-44.

187 BL IOR B/6 A Court of Committee, February 23, 1619. 
as well as their skills as linguists and servants, calling for factors to establish an agreement with the Armenians. However, the factors in Persia saw this as unacceptable, arguing that such a decision should be left 'to our discretion'. ${ }^{188}$ Despite the Persian factors' resistance, the EIC did try to form some form of commercial agreement with the Armenian community in Persia in the 1630s. In 1631 the EIC 'strongly opposed' French attempts to gain access to the silk trade and were joined by the 'Dutch and Armenian Jullfareyns' who form a 'joint faction' with the company. ${ }^{189}$ Several years later, the company in London again proposed a deal with the Armenians, to which the agent in Persia, William Gibson, replied that if they knew any Armenians 'you would never wish us to'. ${ }^{190}$ Gibson went on to list a series of prejudicial characteristics, from them being 'so unfaithful in work and deed' to 'so gripping and deceitful in their dealings' ${ }^{191}$ It was through the factors' inability to deal with the Armenians that the company became further exposed to competition and so failed to secure the silk trade for much of the early part of the century. Despite this inability to negotiate trade, the EIC's naval supremacy in the Persian Gulf following the fall of Portuguese-held Hormuz in 1622 meant the Armenians utilised English shipping to and from India. In March 1632, company agents reported that 'many Armenians' had taken passage 'on our shipps'. ${ }^{192}$ Likewise, many senior Armenian merchants such as Cojah Suffras, 'cheife of the Armenians in Persia, and 'Cojah Pedroffe' would approach and petition the company to either travel or pay for goods to be freighted on EIC ships and in April 1643, Armenians in London requested passage back to Persia. ${ }^{193}$ The EIC diplomatic and commercial relationship with the Armenians would change in the second half of the century; the flexibility of early pastoral governance meant that its effects could, at times, put the company's commercial missions at risk. This was

188 BL IOR E/3/12, Gombroon to Surat, February 20, 1629.

189 BL IOR E/3/12, Edward Heynes and William Gibson on Board the Discovery at Gombroon to the Company in London, March 17, 1631.

190 BL IOR E/3/14, William Gibson, Richard Cooper and William Fall at Isfahan to Company in London, June 26, 1633.

191 Ibid.

192 BL IOR E/3/13, William Gibson, John Sherland, Richard Cooper and William Fall at Gombroon to Company in London, March 22, 1632.

193 BL IOR B/19 A Court of Committee, February 19, 1640; A Court of Committee, March 10, 1640; BL IOR B/21 A Court of Committee, April 4, 1645. 
especially the case when the company was competing against religious communities whose religious governance was far more accustomed to navigating the political and geographical environments that the EIC and LC were operating in.

The religious sentiments of the companies' leadership and chaplaincy provide an insight into the broad Protestant spectrum that was incorporated throughout the companies. In 1664, the orthodox Anglican, and ambassador to the Ottoman Empire Sir Heneage Finch highlighted this issue when he complained of the lack of orthodox chaplains being sent out to Turkey. He placed the blame for this upon the 'companies merchants in England', which, according to him, were mostly 'composed of factious members'. ${ }^{194}$ As suggested earlier, the variants of Protestantism, whether acute or moderate, represented in the high-ranking positions of the companies reflected in the make-up of the companies' chaplaincy. For the most part, the denominational diversity of the chaplaincy would help to establish the religiously sufferant ecumenical governance of the postBraganza EIC. However, in the LC during this early period, it did cause some religious division in the pastoral governance of the companies. One incident that highlights this involved the dismissal of the Nonconformist minister at Smyrna, John Broadgate. Elected by the company to take up the position of chaplain in Smyrna in December 1662, and described as being 'palmed... upon the Turkey Company', Broadgate was seen as a controversial figure and would only spend two years in his post before being dismissed. ${ }^{195}$ Although it was quite likely that the company knew of his Nonconformist background when he was appointed to the chaplaincy, Broadgate's theological persuasion did not seem to go down well with the company leadership in the Levant. Dudley North described him as a 'fanatic and a whimsical pedant' and was horrified at what he saw as Broadgate's attempts to 'erect a discipline and make a Presbyterian reform amongst them'. ${ }^{196}$ Similarly, the Consul at Smyrna, William Cave,

194 Finch Mss., 326.

195 TNA SP 105/152, f. 72; Roger North, The Lives of Francis North, Baron Guildford, Sir Dudley North, and Rev. Dr. John North, vols. 3 (London: Henry Colburn, 1826), I: p. 56; Pearson, A Biographical Sketch, pp. 31-35; Glaisyer, Culture of Commerce, pp. $74-75$.

196 North, North, II: p. 41. 
wrote to the ambassador, Finch, that Broadgate was so 'universally obnoxious none cares for his company'. ${ }^{197}$ Finch himself later complained to the Bishop of London that the chaplain was a 'man of most imprudent and petulant behaviour' and 'malicious spirit'. ${ }^{198}$ However, at the same time that complaints were being raised against the minister by consuls and ambassadors, the company formally acknowledged that they had been 'much prejudiced' against Broadgate and that this had been to his 'great discredit, \& dishonour'. ${ }^{199}$ Such accusations highlight the internal conflicts of this period, often centred on religion, whether as a cloak for personal issues or reflecting genuine differences. Broadgate's attempts notwithstanding, such carping to impose 'discipline' to strengthen the company, and North's reactions, illustrate the power chaplains had to impose and adapt the company's pastoral governance.

Broadgate's Presbyterianism continued to be the subject of much friction in the company. By 15 April the following year, company leadership in Turkey had been successful in obtaining an order to have Broadgate forcibly brought from Smyrna to Istanbul. Having been accused of 'disturbance of the public peace' at Smyrna and of uttering 'several scandalous words to the dishonour of the Consul of that place', a Mr. Richard Morsse was dispatched to bring Broadgate to the ambassador, with permission to use extreme force if necessary. ${ }^{200}$ In the deposition that followed, it was Broadgate's ecclesiastical actions that were seen to be seditious and the focus of the court. A council of three men was chosen to examine the case against Broadgate on 4 May, and their terms of reference were remarkably specific. The three were ordered to inquire into whether the chaplain had gone against 'the late act of Parliament for uniformity of public prayer, set down at the beginning of the new liturgy of the Church of England'. ${ }^{201}$ The deposition heard that Broadgate had not only opened up the chapel to other Christian faiths, but had refused to give a sermon to his congregation after they were unwilling to 'tune a psalm' and had failed to provide the sacraments

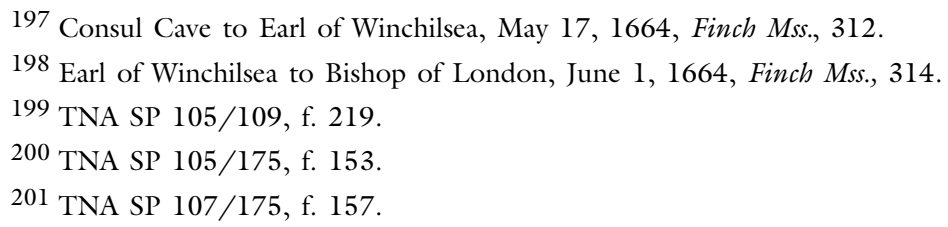


at the Lord's supper, Christmas and Easter. ${ }^{202}$ In doing so, company members argued that he had 'destroyed the charity betwixt himself and them' by neglecting the needs of his parishioners, and that his actions had also brought 'reproach and scandal' upon the 'Protestant religion professed on the Church of England'. ${ }^{203}$ By July 1664, Broadgate had embarked for England, having been dismissed from his post by Finch and other company officials in Turkey. This was not well received by the company in London, who believed that Finch and the others had exceeded their authority in doing so. ${ }^{204}$ The Broadgate debacle illustrates that, during the seventeenth century, the companies' overseas jurisdictions often became the scene of debate surrounding religion. Furthermore, it draws attention to the theological antagonisms of England, which were transported abroad and fought out between the different ranks of the company's personnel. Nevertheless, the corporate religious governance of England's diverse Protestant communities and their chaplaincies overseas were not always so fractious, and in some cases led to forms of toleration and the establishment of ecumenical governance.

\section{CONCLUSION}

By assessing the role of the EIC and LC chaplains in the early years of the seventeenth century, a clear picture emerges of the importance of individuals in establishing and developing religion and pastoral governance as a means of securing and regulating behaviour. Unlike in the religious governance of the $\mathrm{VC}$, the EIC and LC in this period did not have to deal with the challenges that came with territorial acquisition. Consequently, this allowed the chaplains and leadership of the EIC and LC to interact with overseas cultures, adopting pastoral governance and

202 TNA SP 107/175, f. 158; Earl of Winchilsea to Bishop of London, June 1, 1664, Finch Mss., 315.

203 TNA SP 107/175; Earl of Winchilsea to Bishop of London, June 1, 1664, Finch Mss., 315; Opening the chapel up to other faiths was not unheard of and preachers in the Levant company continued to do so after Broadgate had left the Levant. Frampton on several occasions allowed German and Lutherans to attend the chapel. Furthermore, according to Thomas Evans, Frampton would also preach in Italian to ensure that the whole congregation understood him, suggesting that attendance was diverse: $L R F$, pp. $40-42$.

204 Consul Cave to the Earl of Winchilsea, July 13 \& 14, 1664, Finch Mss., 325-26; Glaisyer, Culture of Commerce, p. 75. 
eventually adapting it to suit the companies' unique circumstances. For both the EIC and LC, commerce was the priority, and fearing a similar fate as their Atlantic brethren, they shaped the evangelical wing of their pastoral governance to fit their commercial mission by adopting a passive form of evangelism. Unlike the active evangelism of the VC, in most cases the LC and EIC firmly categorised conversion as a positive by-product of the maintenance of godly behaviour. Despite this, chaplains would prove decidedly influential in the direction of evolution of company religious governance in the pre-Braganza era. EIC and LC chaplains not only influenced pastoral governance across the globe, but through their experiences, interactions and opportunities would also influence religious and academic governance at home. Similarly, the next chapter on the MBC in the years surrounding the Wars of the Three Kingdoms highlights the role of individual members of the company in developing peripheral models of religious governance through connecting to the political and religious debates in England. By the time the EIC was acquiring Bombay in the late 1660s, the pastoral governance established by these early chaplains was evolving into a form of ecumenical governance. The early chaplaincy in the East and its responses to company interaction, behaviour and knowledge would be influential in this evolution.

Open Access This chapter is licensed under the terms of the Creative Commons Attribution 4.0 International License (http://creativecommons.org/licenses/ by $/ 4.0 /)$, which permits use, sharing, adaptation, distribution and reproduction in any medium or format, as long as you give appropriate credit to the original author(s) and the source, provide a link to the Creative Commons license and indicate if changes were made.

The images or other third party material in this chapter are included in the chapter's Creative Commons license, unless indicated otherwise in a credit line to the material. If material is not included in the chapter's Creative Commons license and your intended use is not permitted by statutory regulation or exceeds the permitted use, you will need to obtain permission directly from the copyright holder.

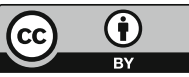

